\title{
IMPACT EVALUATION OF ROAD IMPROVEMENTS AND RURAL POVERTY BASELINE SURVEY IN THE NINGXIA LIUPANSHAN AREA OF THE PEOPLE'S REPUBLIC OF CHINA
}

Masahiro Nishimura, Niklas Sieber, and Sangui Wang

NO. 13

ADB EAST ASIA

June 2018 WORKING PAPER SERIES 

East Asia Working Paper Series

\section{Impact Evaluation of Road Improvements and Rural Poverty- Baseline Survey in the Ningxia Liupanshan Area of the People's Republic of China}

Masahiro Nishimura, Niklas Sieber, and Sangui Wang

No. 13 | June 2018
Masahiro Nishimura is a senior transport specialist in the Transport and Communications Division (EATC), East Asia Department (EARD), Asian Development Bank (ADB). Niklas Sieber and Sangui Wang are consultants for the ADB technical assistance for the preparation of the Ningxia Liupanshan Poverty Reduction Rural Road Development Project. 
(C) 2018 Asian Development Bank 6 ADB Avenue, Mandaluyong City, 1550 Metro Manila, Philippines

Tel +63 2632 4444; Fax +6326362444

www.adb.org

Some rights reserved. Published in 2018.

Printed in the Philippines.

Publication Stock No. WPS189377-2

DOI: http://dx.doi.org/10.22617/WPS189377-2

The views expressed in this publication are those of the authors and do not necessarily reflect the views and policies of the Asian Development Bank (ADB) or its Board of Governors or the governments they represent.

ADB does not guarantee the accuracy of the data included in this publication and accepts no responsibility for any consequence of their use. The mention of specific companies or products of manufacturers does not imply that they are endorsed or recommended by ADB in preference to others of a similar nature that are not mentioned.

By making any designation of or reference to a particular territory or geographic area, or by using the term "country" in this document, $A D B$ does not intend to make any judgments as to the legal or other status of any territory or area.

This work is available under the Creative Commons Attribution 3.0 IGO license (CC BY 3.0 IGO) https://creativecommons.org/licenses/by/3.0/igo/. By using the content of this publication, you agree to be bound by the terms of this license. For attribution, translations, adaptations, and permissions, please read the provisions and terms of use at https://www.adb.org/terms-use\#openaccess.

This CC license does not apply to non-ADB copyright materials in this publication. If the material is attributed to another source, please contact the copyright owner or publisher of that source for permission to reproduce it. ADB cannot be held liable for any claims that arise as a result of your use of the material.

Please contact pubsmarketing@adb.org if you have questions or comments with respect to content, or if you wish to obtain copyright permission for your intended use that does not fall within these terms, or for permission to use the ADB logo.

Notes:

In this report, "\$” refers to United States dollars.

Corrigenda to ADB publications may be found at http://www.adb.org/publications/corrigenda.

The ADB East Asia Working Paper Series is a forum for stimulating discussion and eliciting feedback on ongoing and recently completed research and policy studies undertaken by the East Asia Department of the Asian Development Bank (ADB) staff, consultants, or resource persons. The series deals with key economic and development problems, as well as conceptual, analytical, or methodological issues relating to project/program economic analysis, and statistical data and measurement. The series aims to enhance the knowledge on Asia's development and policy challenges; strengthen analytical rigor and quality of ADB's country partnership strategies, and its subregional and country operations; and improve the quality and availability of statistical data and development indicators for monitoring development effectiveness.

The ADB East Asia Working Paper Series is a quick-disseminating, informal publication whose titles could subsequently be revised for publication as articles in professional journals or chapters in books. The series is maintained by the East Asia Department. 


\section{CONTENTS}

$\begin{array}{ll}\text { I. INTRODUCTION } & 1\end{array}$

II. TRANSPORT INVESTMENTS AND RURAL POVERTY 1

III. THE MAIN CONCEPT OF THE SURVEYS 2

IV. THE SURVEY AREA AND THE ROAD IMPROVEMENT PROJECT 3

A. Liupanshan Area and Road-Improvement Project 3

B. Selection of Survey Villages and Households 3

V. PREPARATION OF THE SURVEY

VI. THE BASELINESURVEY

A. Data Collection $\quad 6$

B. E-Survey Tools $\quad 6$

VII. MAJOR FINDINGS OF THE BASELINE SURVEY 8

A. Poverty and Income $\quad 9$

$\begin{array}{ll}\text { B. Agriculture } & 10\end{array}$

C. Transport 11

VIII. METHODOLOGY FOR THE EX-POST SURVEY AND ANALYSIS 14

A. General Methodological Approach $\quad 14$

B. Treatment of the Exogeneity Assumption 14

C. Indicators for Impact Evaluation 16

$\begin{array}{lll}\text { IX. SUMMARY AND NEXT STEPS } & 18\end{array}$ 


\begin{abstract}
$A D B$ is financing a rural road improvement project in Liupanshan area, a poor and mountainous section of southern Ningxia Hui Autonomous Region of the People's Republic of China (PRC). A baseline survey was conducted before project implementation, and an ex-post survey will be done to assess the impacts of the project on the beneficiaries.

This paper describes the methodology of the impact evaluation and the results of the baseline survey, which used innovative e-survey tools. The paper also provides some scientific background on transport investments and rural poverty. The baseline survey was conducted in 2016 and encompassed 1,188 households in 15 treatment villages and 15 comparator villages. The exact locations and photos of the houses surveyed were recorded using e-survey tools, enabling return visits to the same households for an ex-post survey after the treatment (road improvement), thereby enabling a before-and-after comparisons. The baseline survey results show that no major significant differences were found between the treatment and comparator villages in matching variables. Those variables included household characteristics, agricultural production and income, and the distances to town and markets. The average annual income per capita was about CNY8,280 (\$1,300), which is about 38\% of the national average. The main sources of income were wages (44\%), public transfers (28\%), and agricultural revenues (17\%). Of the households surveyed, $71 \%$ own a motorcycle, which is used mostly for commuting to work. Nearly $75 \%$ of the respondents revealed that travel outside their villages is constrained for a week to a month per year due to bad weather conditions, while 17\% claimed that travel was constrained for 1-2 months, and $7 \%$ claimed up to 4 months. Among all the respondents, bad road conditions were in the top nine factors mentioned as contributing to poverty. The planned methodology for ex-post survey and analysis is also explained.
\end{abstract}

Keywords: impact evaluation, e-survey, rural transport, poverty reduction, road improvement, People's Republic of China

JEL Classification: R4, R42 


\section{INTRODUCTION}

Empirical research supports the view that there are positive impacts from rural road improvements, but a number of questions remain: Who is benefitting most at the village level: the richest or the poorest? How do road improvements influence rural inequalities? Where are the larger expected impacts on agricultural self-employment or on wage income? What impacts do road improvements have on out-migration and daily commuting? Which improvements will have the largest impacts: the provision of access to roads, paving of dirt roads, or widening of feeder roads? And what impacts do road standards have on transport services?

The Government of the People's Republic of China (PRC) has received Asian Development Bank (ADB) financing for a project to provide rural accessibility to roads in the Liupanshan area, a poor and mountainous section of southern Ningxia Hui Autonomous Region (ADB 2016). The project comprises (i) the improvement of priority rural roads, (ii) enhancement of rural road safety and sustainability, and (iii) impact evaluation and capacity building.

This working paper describes the methodology and results of the baseline survey conducted in Liupanshan in the fall of 2016. The survey used innovative e-survey methodologies that will be described in the succeeding sections. This paper provides some technical background on transport investments and rural poverty, and then goes on to describe the baseline survey. Selected results of the survey are presented, and the methodology to be used in the ex-post survey is explained.

\section{TRANSPORT INVESTMENTS AND RURAL POVERTY}

Recent literature reviews were conducted by Sieber and Allen (2016) and Starkey and Hine (2014) on the impacts of rural transport improvements. Research has confirmed that the poor benefit primarily from the indirect impacts of road improvements, such as better access to state and village services and to livelihood opportunities in alternative income streams. Researchers have observed the following major impacts:

(i) Rural roads induced local development through agricultural marketing and increased incomes from farming.

(ii) Revenues from nonfarming activities increased due to rural road improvements, implying a shift from subsistence to commercial farming or to manufacturing.

Starkey and Hine (2014) evaluated 360 documents on transportation and poverty, and they observed that improved rural access in Ethiopia, India, and Nicaragua increased agricultural outputs, improved employment conditions, boosted production, and upgraded the quality of life of people in the affected area. They also indicated that better road access could affect agricultural prices, cropping patterns, land prices, and land ownership. The effect of road improvements on poor households depends on the local circumstances, however, and it should be noted that it is people with resources who are generally the most capable of reacting to changing market conditions and economic opportunities.

Starkey and Hine also mentioned that improvements in feeder roads, paths, and tracks will have a stronger effect on poverty than upgrades of main roads, as more income opportunities are generated when feeder roads, paths, and tracks are rehabilitated for the first time. 
Many authors argue that the improvement of rural roads should be done in locations where there is severe poverty, so as to provide access to markets and opportunities for subsistence farmers, and thus help increase their farm production, marketing, and agricultural incomes.

Other authors argue that the improvement of rural roads should be done in locations where economic opportunities abound, in order to induce more commercial farming and manufacturing activity, which would also generate more employment.

Most authors have focused on the effects of new road construction, without considering the maintenance and preservation of roads for the duration of their design lives. Many roads in developing countries are inadequately maintained because of insufficient public funds, the low priority given to rural roads, and poor management by road bureaus. However, road maintenance generates the highest returns on road investments, so it should be a high priority for operations and research.

\section{THE MAIN CONCEPT OF THE SURVEYS}

ADB initiated a study to measure the social and economic impacts of the trunk- and feeder-road improvements implemented in the Liupanshan area under the Ningxia Liupanshan Poverty Reduction Rural Road Development Project. The methodology of this impact evaluation includes the conduct of two surveys: one ex-ante and one ex-post. However, it is recommended that later follow-up surveys also be conducted, as they will be necessary for evaluating longer-term impacts. The descriptions of the surveys are given below:

(i) A baseline survey (ex-ante) was conducted October-November 2016 to collect comparative data before the implementation of the road-improvement project. A summary of this survey is provided in this paper. ${ }^{1}$

(ii) An end-line survey (ex-post) to analyze the project outcomes and impacts will be conducted in 2021, towards the end of the loan project. The government agreed to use the loan proceeds to conduct this end-line survey.

(iii) Follow-up surveys (ex-post) to analyze longer-term impacts ought to be conducted, as some impacts will not materialize until a few years after the road improvements have been completed.

These surveys will add more insights to the existing knowledge regarding the impacts of rural road improvements on poverty reduction, agricultural production, and migration. Thus far, few surveys of this type have been undertaken in the PRC.

This paper focuses only on the baseline survey. Eventually, the impacts of the road improvements will be estimated by comparing the data from the baseline survey with that collected in the ex-post surveys. In order to screen out the impacts of general economic and social changes felt throughout the region, the surveys also include a control group, consisting of households in villages that will not be affected by any of the road improvements under the Poverty Reduction Rural Road Development Project. A comparison between households in affected villages (treatment villages) and those in unaffected villages (control, or comparator villages) will enable the identification of the impacts that are due to the Project.

1 The baseline survey also utilized cluster research, as developed under Technical Assistance Cluster (C-TA) for Developing Impact Evaluation Methodologies, Approaches, and Capacities in Selected Developing Member Countries, an ADB project implemented in 2013-2017. 
The baseline survey used e-survey tools, so that the same households could be interviewed in the ex-post surveys for better comparability. Proper GIS location data and photographic records of the households surveyed were recorded to ensure survey efficiency. For the data collection, an application called "droidSURVEY" was used, and the data were stored on a website called "Harvest Your Data" (HYD).

\section{THE SURVEY AREA AND THE ROAD IMPROVEMENT PROJECT}

\section{A. Liupanshan Area and Road-Improvement Project}

The Liupanshan area of the Ningxia Hui Autonomous Region is one of the poorest in the PRC. It has a population of 2.39 million, with $38 \%$ of the farmers (over 600,000 people) living under the national poverty line. ${ }^{2}$ The Hui minority makes up $59 \%$ of the region's population. About $77 \%$ of the residents rely on agriculture for their livelihood. The regional government has set a target for the eradication of poverty in the Liupanshan area by the end of 2018 (Ningxia Poverty Alleviation Office 2016).

The road project will improve 267 kilometers $(\mathrm{km})$ of rural trunk roads and $168 \mathrm{~km}$ of rural feeder roads in seven counties in the Liupanshan area. ${ }^{3}$ These counties have a total rural road network of 11,600 $\mathrm{km}$, of which 3,000 km are unpaved and an additional 4,500 km are paved, but in poor or very poor condition. The project roads were selected to enhance poverty reduction in the area, and are expected to benefit 116,000 poor people. Figure 1 shows the map of the area and the locations of the project roads.

\section{B. Selection of Survey Villages and Households}

The selections of the treatment and comparator villages for the baseline survey occurred early on and were discussed with officials in the Transport Bureaus and the Poverty Alleviation Offices at the county level. The counterpart officers at the two county government agencies then matched each treatment village with a comparator village, taking into account not only the project roads, but also road improvements under other initiatives, most notably a government-funded project to improve a number of roads by 2023. Moreover, there had to be some changes during the baseline survey; for example, some villages were abandoned due to high out-migration.

The project roads whose impact will be evaluated by the surveys include six rural trunk roads and nine rural feeder roads. These roads are all $10 \mathrm{~km}$ or longer in length and were selected to cover a wide geographic area within the project counties. Nine of the roads are paved (six trunk roads and three feeder roads), three have gravel surfaces, and three are dirt roads.

One treatment village was selected to correspond to each selected project road. The selection criteria for the treatment villages were as follows: (i) the village must be within $3 \mathrm{~km}$ of the corresponding project road; (ii) the village must be typical of the area in terms of poverty, income, economic activities, and other factors; and (iii) the village must be located near the middle of the project road, not at either end.

The criteria for the selection of the control villages were as follows: (i) the villages had to be located outside the catchment areas of the roads slated to be improved, whether under the project funded by $\mathrm{ADB}$ or that funded by the government; (ii) each control village had to be comparable to a corresponding

2 Since 2011 the official national poverty line is CNY2,300 annual income per capita.

3 The seven counties are Haiyuan, Jingyuan, Longde, Pengyang, Tongxin, Xiji, and Yuanzhou. 


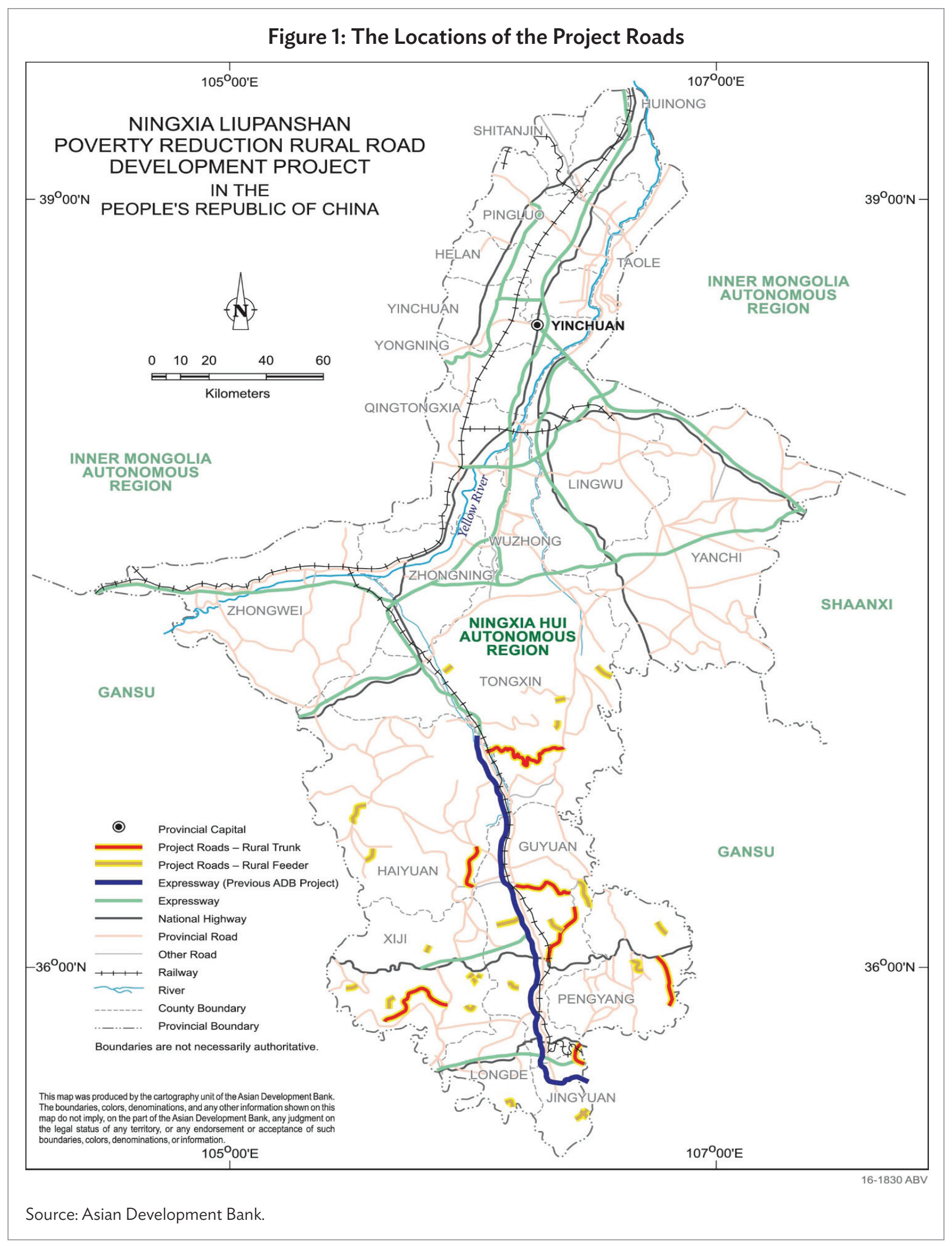


treatment village in terms of poverty, income, economic activities, and other factors; and (iii) the control village and its corresponding treatment village had to be in the same township, to ensure comparability in terms of the general natural and socioeconomic conditions (if no suitable control village could be found in the same township, one was selected in a nearby township).

The treatment and comparator villages were selected by administrative village officials. Generally, an administrative village comprises three to seven natural villages. After the selection of the administrative villages, the administrative village officials selected up to four natural villages under their purview to be part of the survey sample. The selection of natural villages adhered to the following rules: (i) if the administrative village had four or fewer natural villages, all the natural villages were selected; and (ii) if the administrative village had more than four natural villages, four of them were selected randomly.

In order to secure a sufficient sample size for stratified analyses, similar numbers of households were selected across the villages, regardless of village size. On average, 40 households were interviewed in each village. The household selection procedure was as follows: (i) for each natural village that was selected, a list of all the households was made available by the village committee; (ii) if the administrative village contained exactly four natural villages, these four were included in the survey, and 10 households were randomly selected in each; (iii) if the administrative village consisted of three or fewer natural villages, additional households were randomly selected from among all the natural villages until the survey sample of 40 households was reached; (iv) if there were fewer than 10 households in a natural village, additional households were selected from all the other natural villages in the administrative village until the survey sample of 40 households was reached; ( $v$ ) if a household refused to participate in the survey (very rare) or no household member was present during the duration of the survey, the household was replaced by the next one on the household list.

The locations of the treatment and comparator villages, together with that of the project roads, are shown in Figures A1.1 to A1.7, in Annex 1.

\section{PREPARATION OF THE SURVEY}

The questionnaires for the baseline study were developed in English on the HYD website and then translated into Chinese. During the interviews, the data were filled into the questionnaire forms using the droidSURVEY app, which had been installed on the tablets used by the enumerators.

During the week before the survey started, the questionnaires and tablets were tested in the field, but the data collected were not used for the survey. During the actual survey, the collected data were uploaded daily onto the HYD website using a wireless local area network (WLAN). Mobile phone uploads are also feasible. Given that the data were uploaded daily, this method allowed for a fast control of collected data and amendments to the questionnaires. There were two types of questionnaires: the household questionnaires, intended for the selected households, and the village questionnaires, aimed at the village leaders. The questionnaire for the village leaders The village and household questionnaires were both revised several times during the test period to reduce error and improve the outcomes. Eight Chinese enumerators were trained by the national expert, the team leader, and the international expert. 


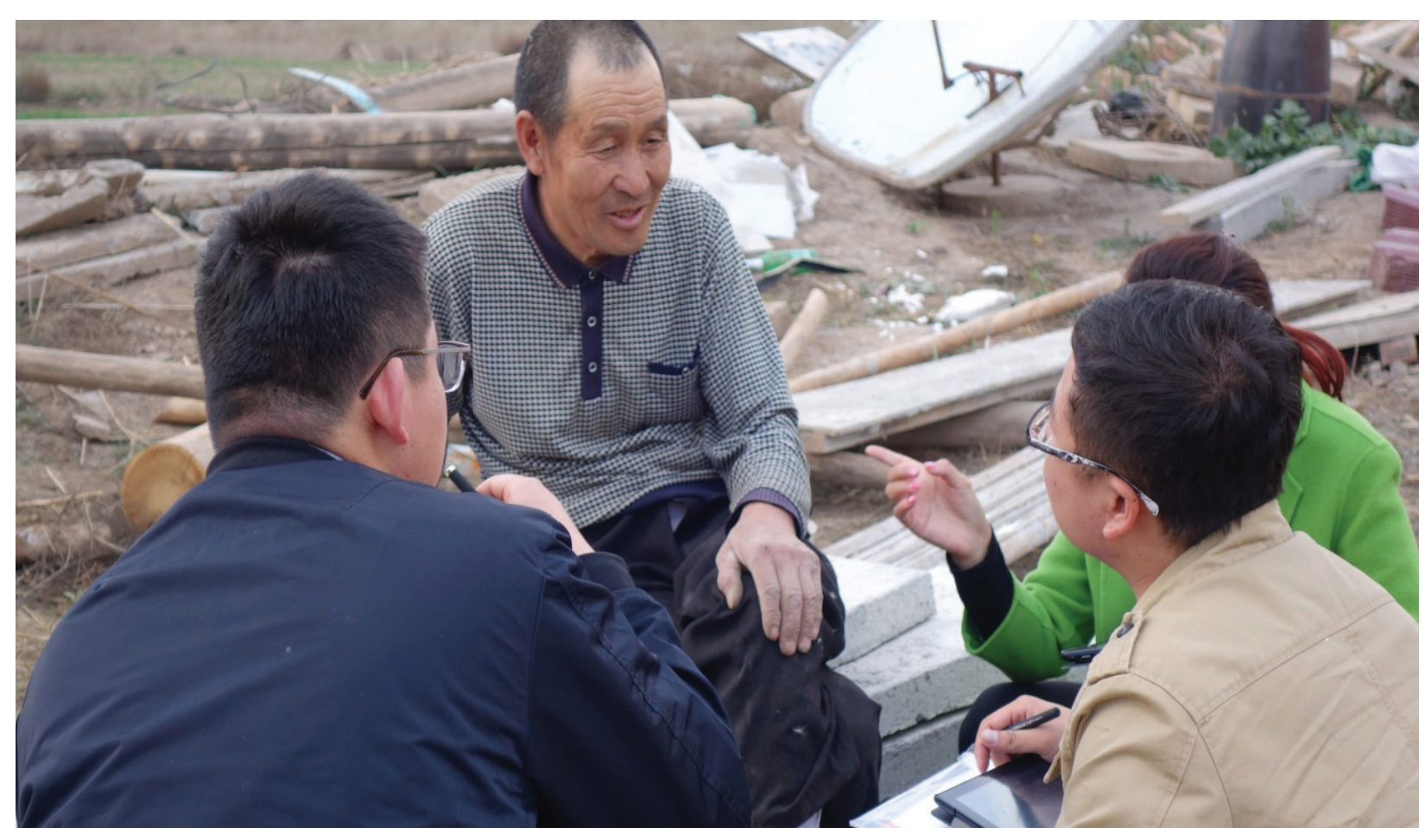

The test phase of the baseline survey. During the test-phase interviews, the enumerators used questionnaires and entered the responses into tablets via the droidSURVEY app (photo by Niklas Sieber).

\section{THE BASELINE SURVEY}

\section{A. Data Collection}

The survey was conducted from 24 October to 27 November 2016. During this period, members of 1,188 households in 30 villages were interviewed; 30 village leaders were interviewed, as well. The survey team consisted of one team leader, who was in the field part of the time, and eight enumerators. Each enumerator conducted four interviews a day. Generally, the duration of the interviews with household members and village leaders was less than one hour, but considerable time was spent in reaching the households. It was therefore essential to organize the survey efficiently.

\section{B. E-Survey Tools}

The HYD droidSURVEY application was installed on the enumerators' tablets to collect the survey data. Tablets were utilized for the survey because they are easier to handle than smartphones. After installation, the tablets were assigned to the HYD website, which served as a repository for all the collected data. Enumerators uploaded daily survey results, photographs, and GPS location data to the website using the WLAN connection. Telephone connections can also be used to upload if there is no WLAN available. The uploaded data were downloaded in the evening so they could be reviewed for inconsistencies and 


\section{Figure 2: Screenshot of English-Language Questionnaire on Harvest Your Data Website}

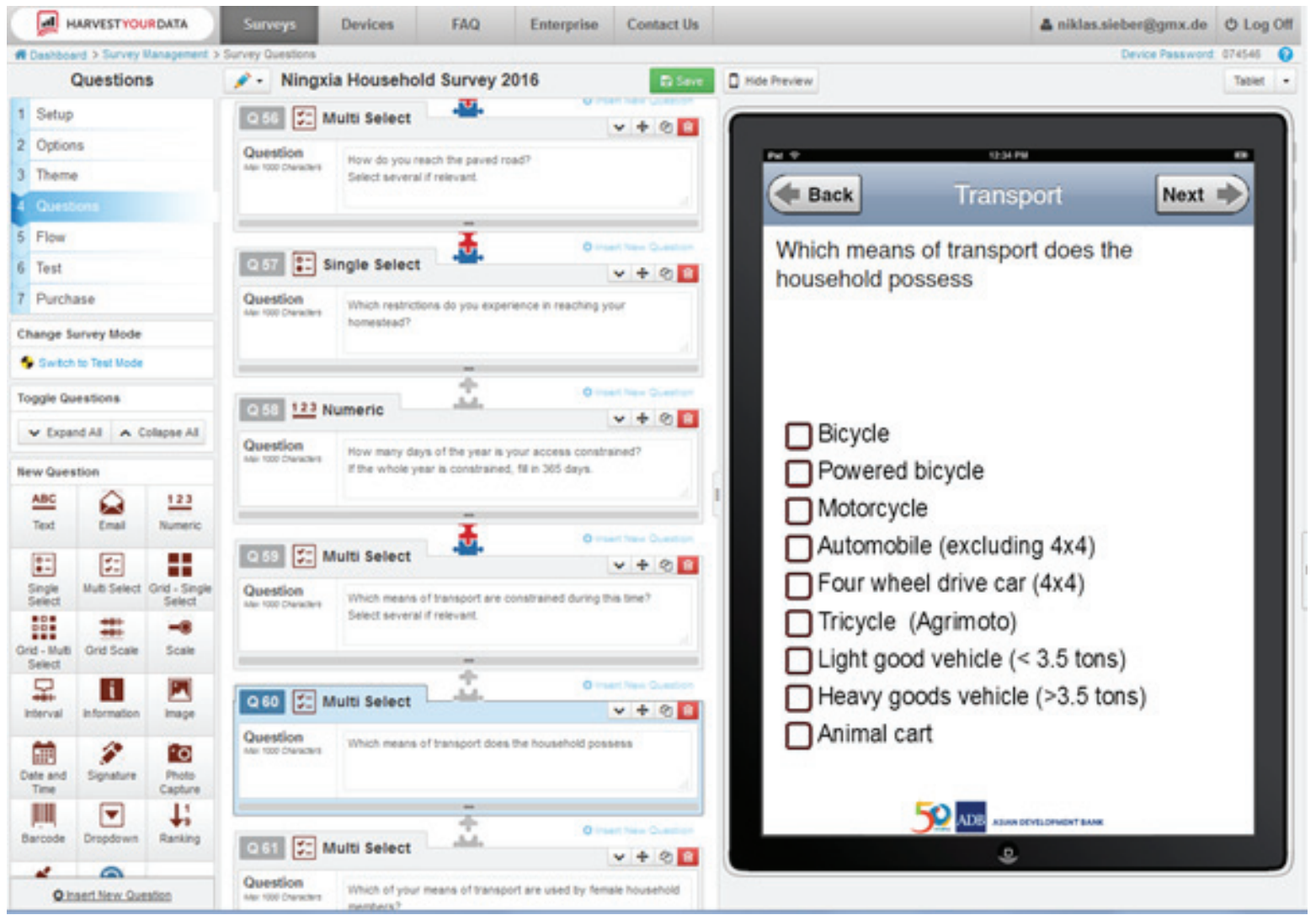

Source: Asian Development Bank; Harvest Your Data. Ningxia Household Survey 2016.

errors. The downloaded data would then be transformed into Excel and Stata formats. After that, there was the first check, done manually, to verify county, township, and village names. Any inaccurate codes or other errors were corrected instantly after consultations with the survey team leader. Several data consistency checks were then done, and all the errors were marked and sent back to the enumerators for correction. The corrected data were compiled and merged together. This enabled the fast control and correction of the collected data.

Figure 2 shows a computer screenshot of the household questionnaire.

Table 1 lays out the numerous advantages of e-surveys compared with conventional paper-based survey methodologies. 
Table 1: Comparison between Conventional and E-Survey Methodologies

\begin{tabular}{|c|c|c|}
\hline Issue & Conventional Survey & E-Survey \\
\hline Method & $\begin{array}{l}\text { (i) Writing survey questions in Word } \\
\text { (ii) Printing questionnaires } \\
\text { (iii) Filling in questionnaire forms during survey } \\
\text { interviews } \\
\text { (iv) Collecting questionnaires } \\
\text { (v) Typing respondents' answers into Excel } \\
\text { (vi) Correcting errors and processing data }\end{array}$ & $\begin{array}{l}\text { (i) Developing survey questions online } \\
\text { (ii) Testing technical devices } \\
\text { (iii) Filling in questionnaire forms on tablets during } \\
\text { survey interviews } \\
\text { (iv) Uploading answers } \\
\text { (v) Downloading respondents' answers into Excel } \\
\text { (vi) Correcting errors and processing data }\end{array}$ \\
\hline $\begin{array}{l}\text { Refinement of } \\
\text { questionnaires }\end{array}$ & $\begin{array}{l}\text { Not possible after the questionnaires are } \\
\text { printed }\end{array}$ & Easy to do during testing phase \\
\hline Error corrections & $\begin{array}{l}\text { At the end of the survey, at which time the } \\
\text { corrections are input into the Excel file }\end{array}$ & $\begin{array}{l}\text { On the next day, allowing for immediate feedback } \\
\text { to enumerators }\end{array}$ \\
\hline $\begin{array}{l}\text { GPS location of } \\
\text { households }\end{array}$ & GPS device or smartphone needed & A tablet provides this automatically \\
\hline \multirow[t]{2}{*}{ Costs } & $\begin{array}{l}\text { (i) Printing of 1,200 household questionnaires } \\
\text { and } 30 \text { village questionnaires. } \\
\text { (ii) Inputing the questions into an Excel file }\end{array}$ & $\begin{array}{l}\text { (i) HYD website fee of } \$ 445 \text { HYD for two surveys } \\
\text { and 3-month use } \\
\text { (ii) Eight tablets at } \$ 293 \text { each, perhaps also for other } \\
\text { uses later on (handed over to ADB's PRCM) }\end{array}$ \\
\hline & Rough estimate: $\$ 2,400^{a}$ & Total costs: $\$ 2,800$ \\
\hline $\begin{array}{l}\text { Additional time } \\
\text { needed }\end{array}$ & Input of data into Excel and printing: 40 days ${ }^{b}$ & Installation and testing of eight devices:1 day \\
\hline
\end{tabular}

GPS = Global Positioning System, HYD = Harvest Your Data, PRCM = People's Republic of China Resident Mission.

a This rough cost estimate is based on the assumption of 40 days at $\$ 60$ per day (including the salaries of the enumerators).

b The duration of this task is assumed to be 15 minutes per questionnaire.

Source: Asian Development Bank.

\section{MAJOR FINDINGS OF THE BASELINE SURVEY}

The main demographic features of the villages are given in Table 2. Among them is the average number of employed persons per household: it is nearly one per household, most of whom are migrant workers.

Table 2: The Main Demographic Features of the Survey Villages

\begin{tabular}{lccc}
\hline \multicolumn{1}{c}{ Demographic Feature } & Treatment Villages & Comparator Villages & All Villages \\
\hline Total number of villages & 15 & 15 & 30 \\
Total number of households & 594 & 594 & 1,188 \\
Average number households per village & 432 & 390 & 411 \\
Average household size & 4.2 & 4.2 & 4.2 \\
Average number of jobholders per household & 1.00 & 0.93 & 0.96 \\
Average number migrant workers per village & 305 & 281 & 293 \\
Average number of migrant workers per household & 0.71 & 0.72 & 0.71 \\
\hline
\end{tabular}

Source: Asian Development Bank. 


\section{A. Poverty and Income}

In the Liupanshan area, $38 \%$ of the farmers are considered poor, ${ }^{4}$ but the villages differ widely in the number of poor households they have, with the proportions ranging from $0 \%$ to $68 \%$. Regarding the causes of poverty, the lack of credit and lack of skills were deemed the most important by the respondents. Bad access to roads ranked only sixth out of nine possible causes.

The health statistics reveal a difficult situation: In the villages, $23 \%$ of all inhabitants are sick, with $18 \%$ suffering from chronic illnesses. This is due to the fact that many of the healthy young people migrate out, leaving the old and sick at home.

The average annual household income is CNY33,116 (\$4,900), with a range from CNY22,005, in Haiyuan County, to CNY38,677, in Xiji County. The income distribution amongst the villagers is very unequal, with the richest $10 \%$ receiving $29 \%$ of total income. The Gini coefficient was calculated at 41. This reflects the income distribution in People's Republic of China (PRC) as a whole, but it is high compared with Europe, where the Gini coefficient is around 30\%. The main sources of income were wages (44\%), followed by public transfers (28\%) and agricultural revenues (17\%). Surprisingly, private transfers accounted for less than $5 \%$ of income.

Of those village residents with jobs, 55\% are migrant workers, employed outside the county; $24 \%$ work within the county; $6 \%$ within the township; and only $15 \%$ within the village. Regarding the economic sectors, $25 \%$ work in agriculture, $35 \%$ in industry, and the remaining $40 \%$ in services.

Figure 3: Sources of Income in the Survey Villages

(\%)

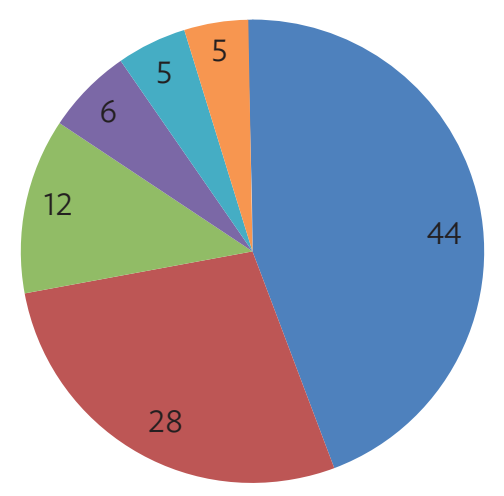

$$
\begin{aligned}
& \text { - Wages } \quad \text { Public transfers } \quad \text { Livestock marketing } \\
& \text { - Business } \quad \text { - Private transfers } \quad \text { Crop marketing }
\end{aligned}
$$

Source: Asian Development Bank.

4 Poor households were identified by the local authorities and village committees based on (i) the national poverty line of CNY2,300 per year at 2010 constant prices; and (ii) the households' actual expenditures on food, closing, housing, education, and health care. 


\section{B. Agriculture}

The relatively low significance of crops is reflected in the statistics for the production and marketing of agricultural products. The average value of annual agricultural production per household is calculated at CNY11,891 (\$1,760), of which roughly half $(C N Y 5,824)$ is sold in markets. Crops comprise only one-fifth of the total value of all the agricultural products marketed by the households, with cattle, goats, and pigs being much more important (Table 3).

Table 3: Agricultural Production and Marketing in the Survey Villages

\begin{tabular}{lccc}
\hline \multicolumn{1}{c}{ Product } & $\begin{array}{c}\text { Production per } \\
\text { Household } \\
\text { (CNY/year) }\end{array}$ & $\begin{array}{c}\text { Marketing per } \\
\text { Household } \\
(\text { CNY/year) }\end{array}$ & $\begin{array}{c}\text { Share of Marketing } \\
(\%)\end{array}$ \\
\hline Potatoes & 541.4 & 442.4 & 81.7 \\
Corn (maize) & 711.4 & 588.7 & 82.8 \\
Fennel & 141.4 & 141.4 & 100 \\
Cattle & $7,319.6$ & $2,790.0$ & 38.1 \\
Goats & $2,481.6$ & $1,348.8$ & 54.4 \\
Pigs & 183.9 & 101.8 & 55.3 \\
Other products & 511.5 & 410.8 & 80.3 \\
All products & $11,890.8$ & $5,823.9$ & 49.0 \\
\hline
\end{tabular}

Source: Asian Development Bank.

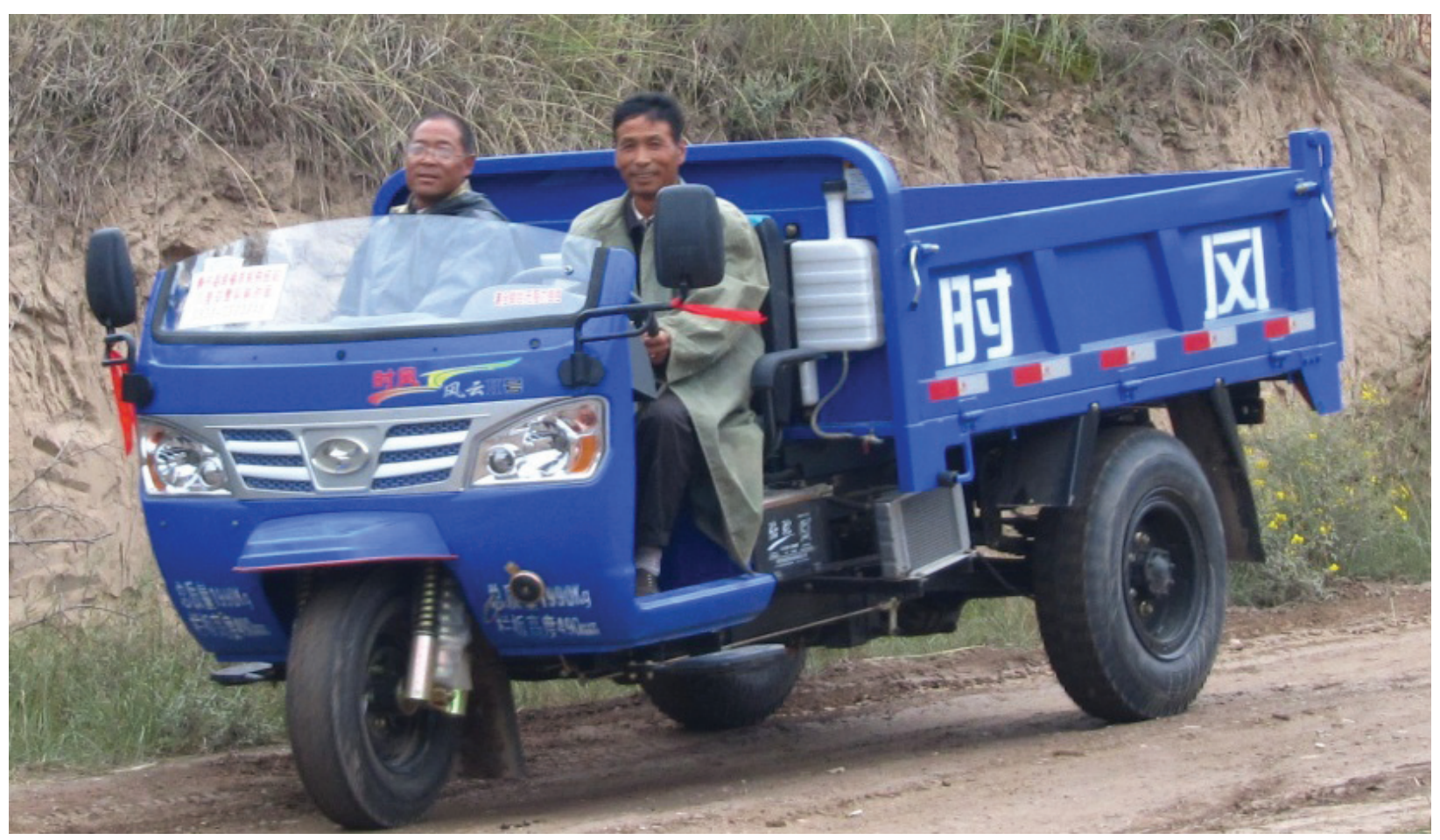

A commonly used farm vehicle. Most villagers transport their crops to market in "tricycles," small one-cylinder, three-wheeled trucks (photo by Niklas Sieber). 


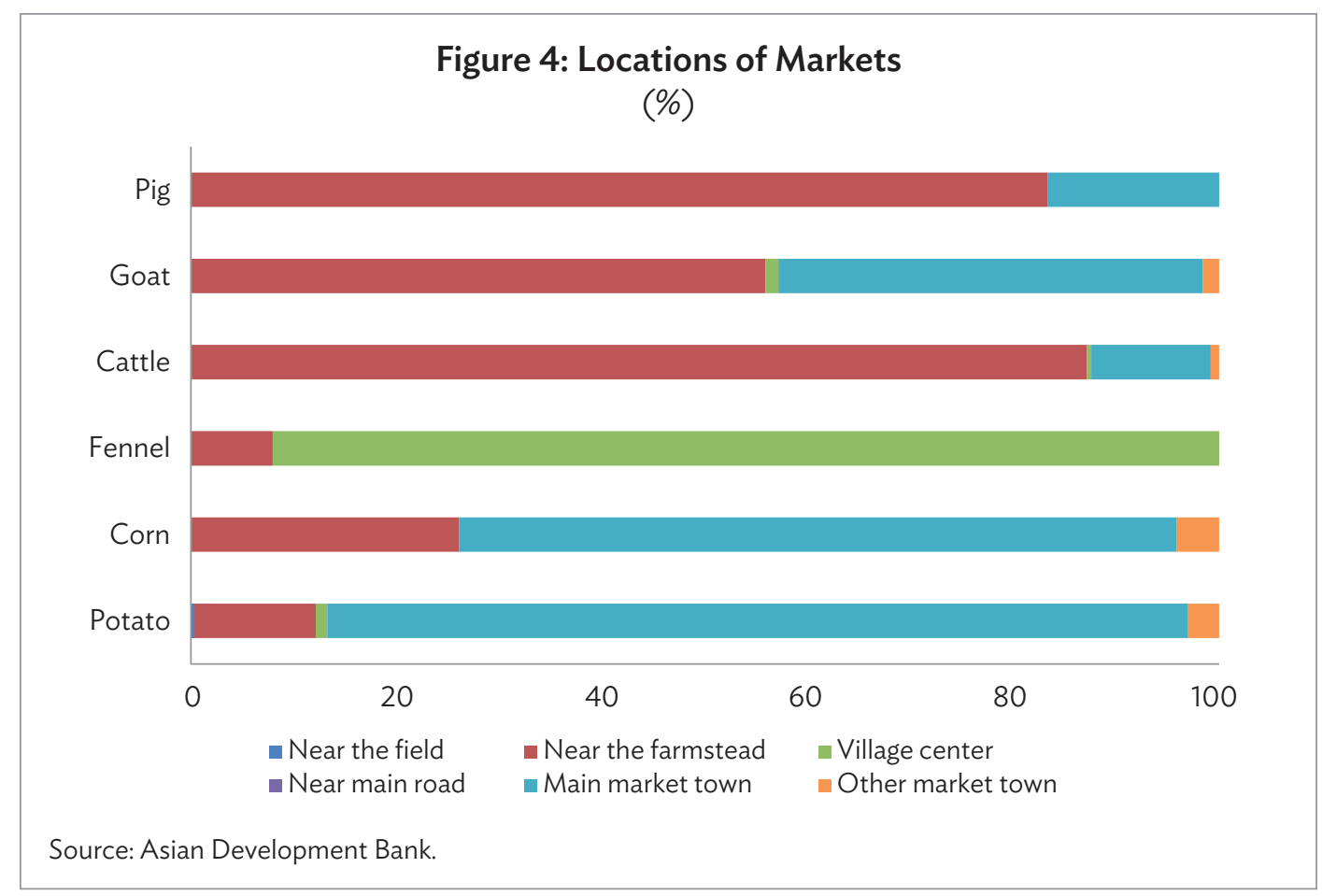

Of the crops produced in the survey villages, 95\% are transported in one-cylinder, three-wheeled trucks called "tricycles" (see photo), which are built specifically for farm use. Most households that produce crops (71\%) own a tricycle, while $20 \%$ of these households rent them, and $4 \%$ transport their crops through traders. With regard to livestock, $78 \%$ are transported in tricycles and $15 \%$ in light four-wheeled trucks (less than 3.5 tons). Traders collect $43 \%$ of the animals, while $41 \%$ are transported by villagers in their own vehicles and $16 \%$ by villagers in rented vehicles.

The cost of transporting crops to the market equals up to $7.4 \%$ of the revenues gained through marketing. The locations for marketing agricultural products vary: livestock is sold near the farmstead, fennel in the village center, and corn and potatoes in the main market town. Only $0.1 \%$ of harvested value is lost due to the differing locations of markets for various agricultural products, so this factor is not considered one of the causes of poverty. Figure 4 shows the locations of the markets for various agricultural products.

\section{Transport}

The possession of transport vehicles is widespread in the survey villages, with $71 \%$ of the households owning a motorcycle, $60 \%$ a tricycle, $17 \%$ a motorized bicycle, and $15 \%$ an ordinary bicycle. However, these vehicles are mostly used by men. In $24 \%$ of the households, women do not use any of the means of transport; in 13\%, they use a motorbike; in 11\%, a motorized bicycle; and in $7 \%$, an ordinary bicycle (Figure 5). 


\section{Figure 5: Means of Transport to Local Destinations}

$(\%)$

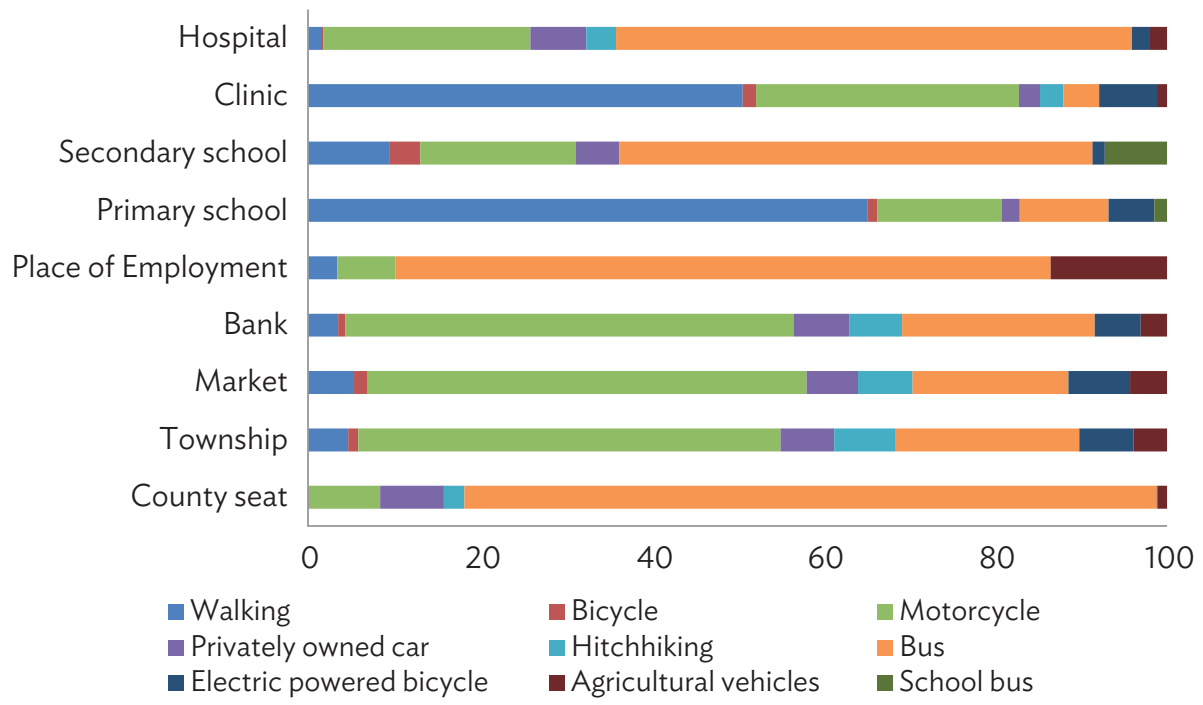

Note: This graph shows the average rates of use of various means of transportation in the survey villages. Source: Asian Development Bank.

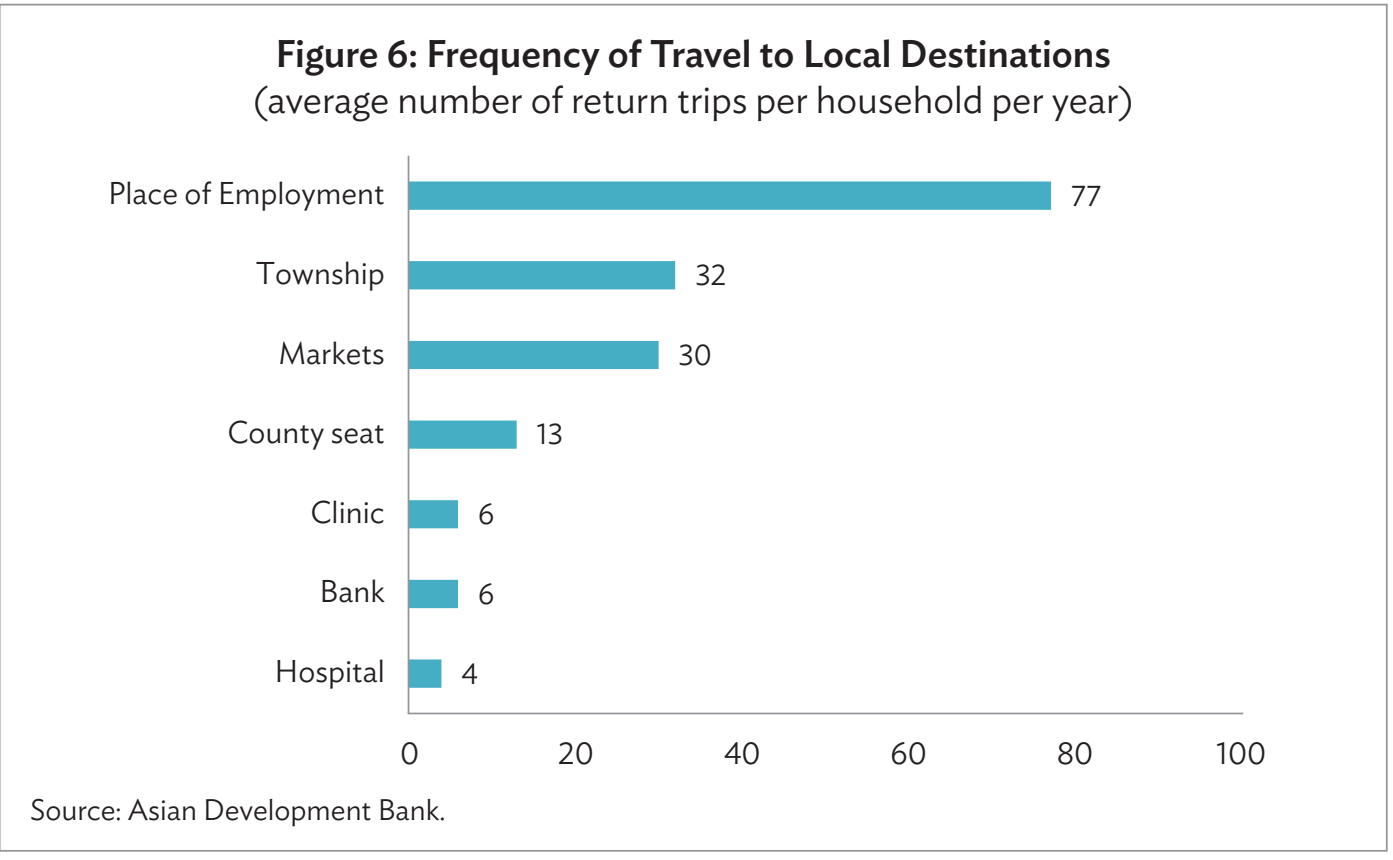

Figure 6 shows only trips to local destinations outside the village-to places of employment, county and township administration offices, banks, clinics, hospitals, and markets. An average household makes 168 trips per year. Places of employment are the most frequent destination, followed by the township administration offices and markets. The villagers use various means of transportation, depending on the destination. Buses are typically used to go to the hospital, secondary school, place of employment, and 


\section{Figure 7: Distances from Village Households to the Nearest Paved Road}

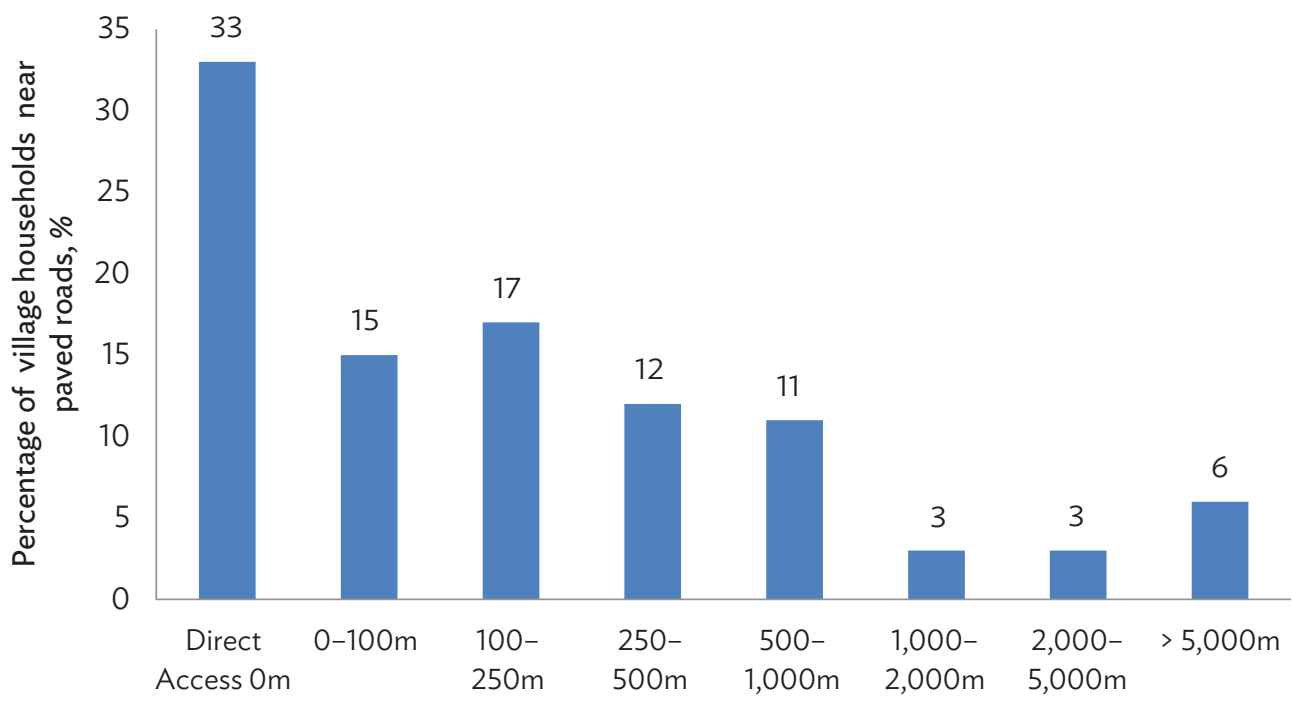

$\mathrm{m}=\operatorname{meter}(\mathrm{s})$.

Note: The percentages represent the proportion of households within each range of distances from the nearest paved road.

Source: Asian Development Bank.

the county seat. The motorcycle is the preferred mode for going to the bank, markets, and the township. Primary school pupils usually walk to school, and students in secondary school tend to make one round bus trip per week, as they usually attend boarding schools.

Nearly $75 \%$ of the village survey respondents revealed that external access is limited for a period of 1 week to 1 month a year due to bad weather conditions; 17\% claim that external access is limited during 1 to 2 months, and $7 \%$ claim that it is limited for up to 4 months.

One-third of the households have direct access to a paved road, another third is within 250 of a paved road, while $12 \%$ are farther away than one kilometer $(\mathrm{km})$ (Figure 7$){ }^{5}$

An ambulance can directly reach $75 \%$ of the villages in good weather conditions. However, in bad weather, the proportion drops to $50 \%$. The maximum distance sick people have to be carried to an ambulance varies between 100 meters and $8.5 \mathrm{~km}$.

The household questionnaires are presented in Annex 2, and the village questionnaires are presented in Annex 3.

5 The paved roads here are not necessarily connected to larger networks. For instance, a road might be paved only within a village. These aspects of road networks will be analyzed after the end-line survey, which will be based on the data from local transport bureaus. 


\section{METHODOLOGY FOR THE EX-POST SURVEY AND ANALYSIS}

\section{A. General Methodological Approach}

The impacts of road improvements will be estimated by comparing the data from the baseline survey with those from the ex-post surveys. The control group was included in the survey so that the impacts of the road-improvement project could be separated from the general economic and social changes occurring in the region. Thus, the impacts on the treatment villages should be compared with those experienced by comparable households in villages without road improvements (i.e., the comparator, or control, villages); and this should be done by using double difference regression techniques.

The following methodology may be applied:

\[ Y_{i}=\Delta R Y_{i}-\Delta N Y_{i} \]
$Y_{i}=\quad \begin{array}{ll}\text { Impact on indicator } i \\ \Delta R Y_{i}=\end{array}$
$\Delta N Y_{i}=\begin{aligned} & \text { Change in indicator } i \text { in treatment villages before and after road improvement } \\ & \text { Change in indicator } i \text { in villages with } N O \text { road improvement during the same time period } \\ & \text { (control group). }\end{aligned}$

\section{B. Treatment of the Exogeneity Assumption}

Since the treatment and comparator villages cannot be randomly assigned, the propensity score matching (PSM) method was adopted. PSM has the advantage of being less reliant on distributional assumptions. This can mean less bias, but possibly at the expense of precision (Imbens 2004; Abadie and Imbens 2006). To estimate the real effects on the treatment group, the selection of groups is based on observed variables, so that systematic differences in outcomes between treatment- and control-group observations with the same values of the covariates can be attributed to the effects of the road-improvement project. To estimate the treatment effects on the matching estimators, exogeneity is assumed.

Smith and Todd (2005) suggested that to improve the reliability of the estimation, geographic disparity between matched observations should be avoided, survey questions and survey methods should be identical for both the treatment and control groups, and difference-in-differences matching should be used for cross-sectional matching. Abadie and Imbens (2006) proposed a method for eliminating bias caused by imprecise matching of covariates between treatment- and control-group observations; their method uses nearest neighbor matching with a fixed number of matches.

For each treatment observation $i$, the following expression is used to estimate the dependent variables in the treatment group, $\mathrm{Y}_{\mathrm{i}}$, wherein $\mathrm{Y}_{\mathrm{i}}=\left(\tilde{Y}_{i}(0)\right)$ if there is no treatment and $\mathrm{Y}_{\mathrm{i}}=\left(\tilde{Y}_{i}(1)\right)$ if treatment has occurred:

$$
\begin{aligned}
& \tilde{Y}_{i}(0)=\frac{1}{M} \sum_{j=\Im_{M}(i)}\left(Y_{j}+\hat{\mu}_{0}\left(X_{i}\right)-\hat{\mu}_{0}\left(X_{j}\right)\right) \\
& \tilde{Y}_{i}(1)=Y_{i} .
\end{aligned}
$$


From equation $1, \hat{\mu}_{0}$ is a fitted linear regression function of $Y_{j}$ on independent variables $X_{j}$ using the control observations. It is used to adjust the estimates to account for differences in the matching variables for each treatment observation $\left(X_{i}\right)$ and its matched control observation $\left(X_{i}\right)$. This correction leads to an unbiased estimate of the average treatment effect on the treated group, which can be expressed as:

$$
\tau=\frac{1}{N_{1}} \sum_{W_{i}=1}\left(Y_{i}-\tilde{Y}_{i}(0)\right)
$$

where $\mathrm{N}_{1}$ is the number of treatment observations and $\mathrm{W}_{\mathrm{i}}$ signifies observations in the treatment group (Abadie and Imbens 2006).

Some matching variables $X$ reflecting village characteristics and their summary statistics are listed in Table 4. Those variables include household size, number of female-headed households, poverty incidence, income per capita, consumption per capita, number of jobholders per household, crop revenues, livestock revenues, variety of crops, variety of livestock, distance to the local township, and distance to the main markets. In the t-test results, no significant differences were found between the treatment and comparator villages for eight variables, but the treatment villages were found to have high values for the other four variables (consumption per capita, number of jobholders per household, agricultural revenues, and variety of crops). Thus, the treatment and comparator villages were to a large extent comparable, although the treatment villages were better off in some cases with regard to crop production, employment, agricultural income, and consumption.

A more detailed presentation of the comparisons between the treatment and comparator villages is provided in Annex 4.

Table 4: Matching Variables before the Surveys

\begin{tabular}{lcrrl}
\hline \multicolumn{1}{c}{ Variables } & Unit & $\begin{array}{c}\text { Treatment } \\
\text { Villages }\end{array}$ & $\begin{array}{c}\text { Comparator } \\
\text { Villages }\end{array}$ & \multicolumn{1}{c}{ T-Test } \\
\hline Household size & No. & 4.30 & 4.29 & No significant difference \\
Female-headed households & $\%$ & 2.9 & 3.2 & No significant difference \\
Poverty incidence & $\%$ & 30.7 & 30.2 & No significant difference \\
Income per capita & $\mathrm{CNY}$ & $8,671.3$ & $7,892.8$ & No significant difference \\
Consumption per capita & $\mathrm{CNY}$ & $5,491.1$ & $5,057.2$ & Treatment villages were higher \\
Jobholders per household & No. & 1.00 & 0.93 & Treatment villages were higher \\
Agricultural revenues per & $\mathrm{CNY}$ & $2,183.3$ & $1,039.9$ & Treatment villages were higher \\
household & & & & \\
Livestock revenues per household & $\mathrm{CNY}$ & $1,931.8$ & $2,723.5$ & No significant difference \\
Kinds of crops per household & No. & 0.66 & 0.59 & Treatment villages were higher \\
Kinds of livestock per household & No. & 0.47 & 0.52 & No significant difference \\
Distance to township & $\mathrm{km}$ & 13.5 & 11.4 & No significant difference \\
Distance to main markets & $\mathrm{km}$ & 11.67 & 12.67 & no significant difference \\
\hline
\end{tabular}

$\mathrm{CNY}=$ Chinese yuan, $\mathrm{km}=$ kilometer, No. = number.

Source: Asian Development Bank. 
Contamination of the control group can occur, as quite a few road-improvement projects are planned under the Ningxia Hui Autonomous Region 13th Five-Year Plan, in addition to the central government's plans mentioned above. For this reason, close attention should be paid to the ex-post analyses, as these government projects will affect the control villages. These problems will be very hard to deal with because there might be no reliable basis for comparison, and the limited number of treatment and control villages will make it even more difficult to estimate the treatment effects. An alternative approach would be to use an ordinary least squares (OLS) regression at the household level, in order to track the impact of changes in road access for a sample of households based on economic and social welfare indicators. As household accessibility to roads was directly measured during the baseline survey, and will be measured again during the follow-up surveys, the analysis will not have to rely on the control groups. The reliability of OLS estimations will depend on the exogeneity of road-access variables. Instrumental variables may be needed for an unbiased estimation.

\section{Indicators for Impact Evaluation}

This section describes the impacts that will be assessed during the ex-post surveys. The main question is: Which of the expectations laid out in the project proposal have materialized? The project document describes the issues to be studied as follows:

\section{Impacts on Poverty}

These surveys focus strongly on poverty alleviation, and the impacts at the household level will be assessed through a combination of variables such as household income, household expenditures, household endowment, number of jobholders, and the marketing of products. The assessment will also be based on a comparison of housing conditions, using photos taken during the baseline survey. The main questions are: How strong was the impact of road improvements on poverty alleviation? How strong is the nexus between road improvement and poverty? How were rural inhabitants able to escape the poverty trap-through intensified farming or through new employment opportunities?

\section{Indicators}

On the basis of the baseline survey, the following indicators will be assessed:

Table 5: Indicators for the Impact Evaluation

\begin{tabular}{lll}
\hline \multicolumn{1}{c}{ Social } & \multicolumn{1}{c}{ Economic } & \multicolumn{1}{c}{ Transport } \\
\hline Poverty & Income and expenditures & Transportation patterns \\
Health & Employment & Frequency of travel \\
Education & Crop production and marketing & Travel time \\
Gender issues & Livestock production and marketing & Means of transport used \\
Out-migration ${ }^{a}$ & Other income-generating activities & Village access to roads \\
& Tourist attractions & The time it takes for ambulances to arrive \\
& Industries & Distance from the household to the paved-road \\
& & network \\
& & Transportation costs \\
& Availability of public transport \\
& Transport safety \\
\hline
\end{tabular}

a This refers to changes in the number of persons who are not permanently present in the surveyed households. Source: Asian Development Bank. 


\section{Comparison of Network Improvements in Access to Paved Roads}

One of the most important questions concerns the effects of network improvements in the provision of access to paved roads. This question may provide guidance for future road-investment strategies focusing on rural poverty alleviation. Overall, the expected network improvements are as follows:

(i) Network efficiency will be improved for existing paved roads, and especially for newly paved feeder roads, through widening, reduction of road roughness, and the fixing of horizontal and vertical alignments. These improvements will increase speed, reduce travel time, lower transport costs, and enable larger vehicles to use the roads.

(ii) Access will be improved through the paving of dirt and gravel feeder roads. The baseline study revealed that access of the village households to paved roads is seasonally hampered by weather conditions.

This project provides a good opportunity to gauge with greater precision the treatments' economic impacts, given that the trunk and feeder roads are not directly connected in the network.

\section{Comparison of Feeder and Trunk Road Impacts}

The surveys will also enable an analysis of which types of road improvements will have stronger impacts. The project delivers a number of interesting options by improving both feeder and trunk roads, paving dirt and gravel roads, and by improving the condition of existing paved roads. Table 6 shows that there are five possible combinations of road-improvement options.

Table 6: Types of Road Improvements

\begin{tabular}{lcl}
\hline Roads & Present Standard & Future Standard \\
\hline Trunk roads & Gravel & Paved \\
Feeder roads & Paved & Paved and improved \\
& Dirt & Paved \\
& Gravel & Paved \\
& Paved & Paved and improved \\
\hline
\end{tabular}

Source: Asian Development Bank.

\section{Additional Information to be Collected}

In addition to the surveys of households in the treatment and control villages, and of the village leaders, it is recommended that other information be collected to augment the survey data and enable an accurate interpretation of the survey findings. The idea is to capture more information on road impacts than could be gleaned just from the village respondents. The following additional types of information could be used:

(i) statistics on the amount of traffic,

(ii) accident statistics,

(iii) roadside interviews, and

(iv) interviews with selected administrators and private transport entrepreneurs. 


\section{SUMMARY AND NEXT STEPS}

Other research has shown that rural road improvements indirectly benefit the poor by generating more income opportunities. The village surveys described in this paper also seek to gauge how road improvements affect the poor, in this case by evaluating the benefits of the Ningxia Liupanshan Poverty Reduction Rural Road Development Project for the poor residents of the Liupanshan area. This paper has described the techniques and methodologies underlying the surveys and the analyses that will follow. Actual-results-chain and cause-and-effect analysis could be beneficial for the further planning of rural road projects in the Liupanshan area and elsewhere. The impact evaluation based on these surveys will provide such analyses, based on the differences observed between the baseline-survey and end-line-survey results.

So far, the baseline survey has confirmed that most of the matching variables did not show significant differences between the treatment and comparator villages before the road improvements began. For instance, the incidence of poverty in treatment villages averaged $30.7 \%$, and that of the control villages averaged 30.2\%. The next (mid-line or end-line) survey and impact evaluation will be conducted under the Ningxia Liupanshan Poverty Reduction Rural Road Development Project shortly after the project's completion. Further follow-up studies may be conducted to observe longer-term changes. 


\section{REFERENCES}

Abadie, Alberto, and Guido W. Imbens. 2006. "Large Sample Properties of Matching Estimators for Average Treatment Effects.” Econometrica 74, no.1 (January): 235-267. https://economics.mit.edu/ files/11867.

Asian Development Bank (ADB). 2016. Project to the People's Republic of China for the Ningxia Liupanshan Poverty Reduction Rural Road Development Project. Manila.

20XX. Technical Assistance Cluster (C-TA) for Developing Impact Evaluation Methodologies, Approaches, and Capacities in Selected Developing Member Countries. Manila.

Hettige, Hemamala. 2006. When Do Rural Roads Benefit the Poor and How? An In-Depth Analysis Based on Case Studies. Manila: ADB. https://www.adb.org/sites/default/files/publication/29406/ when-rural-roads-benefit-poor.pdf.

Imbens, Guido W. 2004. "Nonparametric Estimation of Average Treatment Effects under Exogeneity: A Review." The Review of Economics and Statistics 86, no. 1 (February): 4-29. https://faculty.smu.edu/ millimet/classes/eco7377/papers/imbens\%2004.pdf.

KfW. 2013. German Financial Cooperation with Cambodia, Rural Infrastructure Programme (RIP) II, Ex-Post Social Impact Assessment. Report. Frankfurt, Germany: KfW.

People's Government of the Ningxia Hui Autonomous Region, Ningxia Poverty Alleviation Office. 2016. 13th Five-Year Poverty Reduction Plan. Yinchuan, Ningxia Hui Autonomous Region, People's Republic of China (PRC).

Sieber, Niklas. 2009: Leapfrogging from Rural Hubs to New Markets: Rural Transport in Developing Countries. Freight Transport for Development Toolkit. Washington, DC: The World Bank.

Sieber, Niklas, and Heather Allen. 2016. "Impacts of Rural Roads on Poverty and Equity." Transport and Communications Bulletin for Asia and the Pacific 86 (Sustainable Rural Access): 23-40.

Smith, Jeffrey, and Petra Todd. 2005. "Does Matching Overcome Lalonde's Critique of Nonexperimental Methods?" Journal of Econometrics 125, no. 1-2: 305-353.

Starkey, Paul, and John Hine. 2014. "Poverty and Sustainable Transport: How Transport Affects Poor People with Policy Implications for Poverty Reduction; A Literature Review." Report prepared for the Overseas Development Institute (ODI), United Nations Human Settlements Programme (UN-Habitat); the Partnership on Sustainable, Low Carbon Transport (SLoCaT); and Department for International Development, London, United Kingdom, and Nairobi, Kenya. https:// sustainabledevelopment.un.org/content/documents/1767Poverty\%20and\%20sustainable\%20 transport.pdf. 


\section{ANNEX 1: MAPS OF SURVEYED VILLAGES}

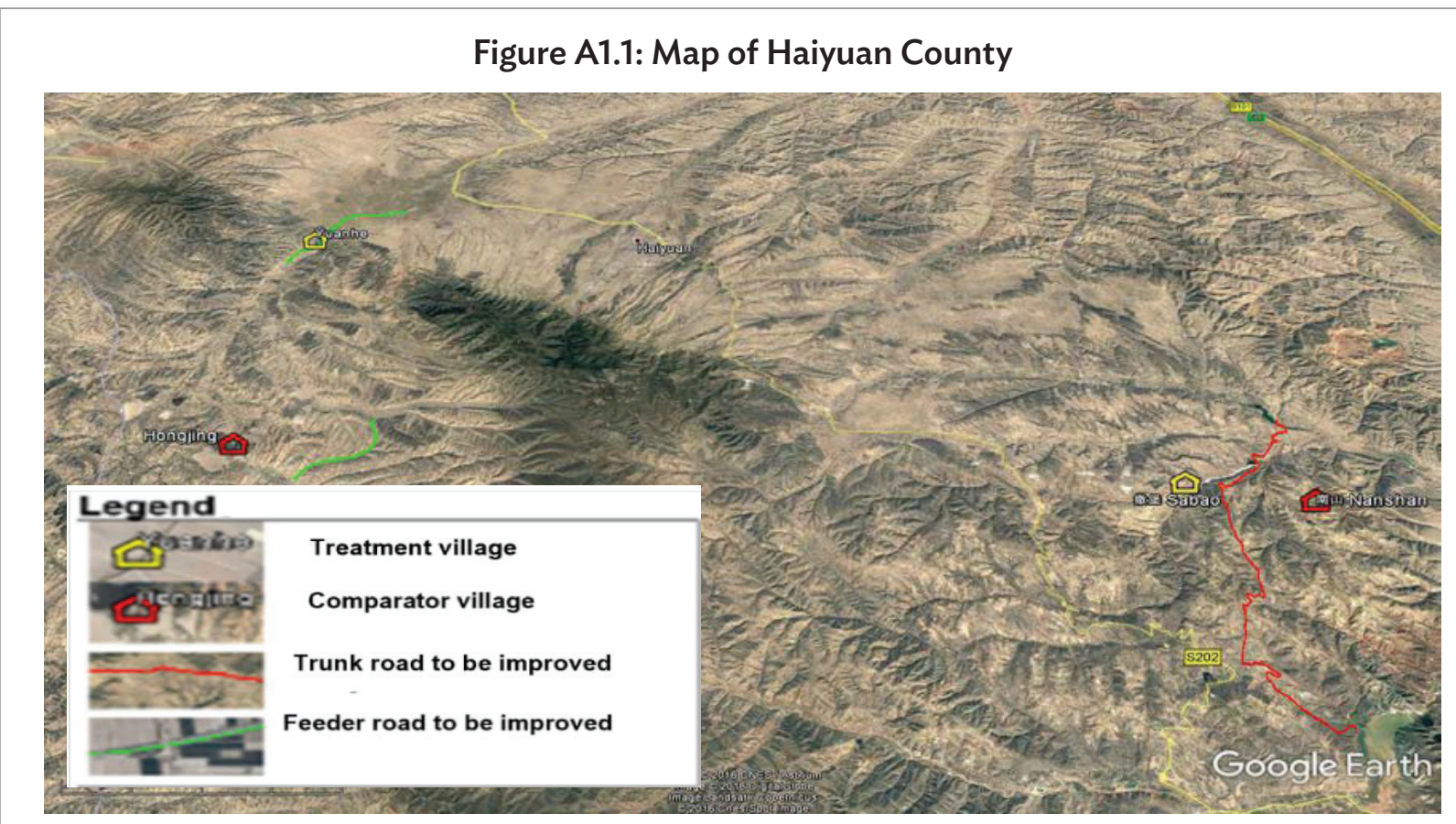

Note: Location of trunk and feeder roads near treatment and comparator villages. Map Data: Google Earth; Annotations: ADB.

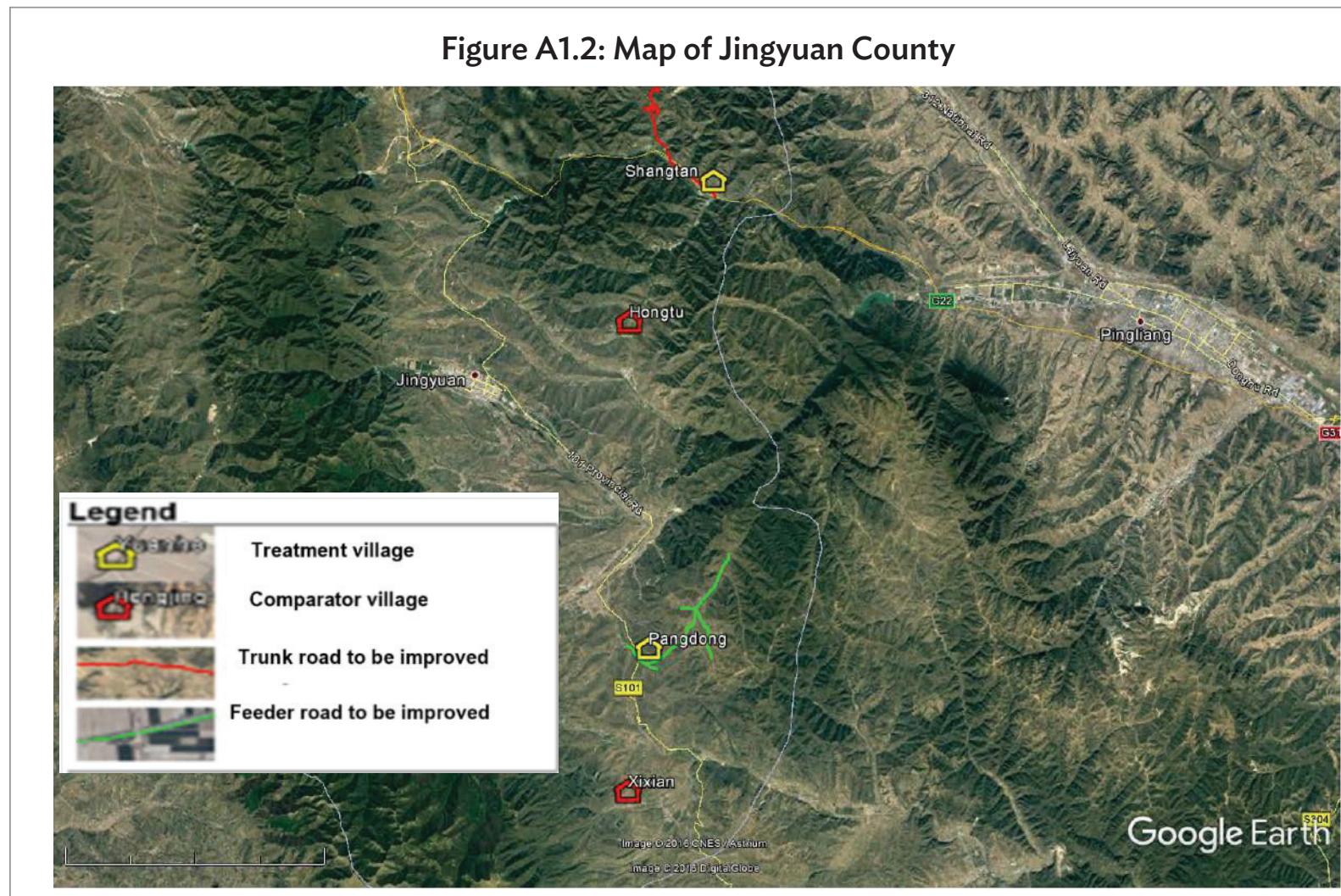

Note: Location of trunk and feeder roads near treatment and comparator villages. Map Data: Google Earth; Annotations: ADB. 


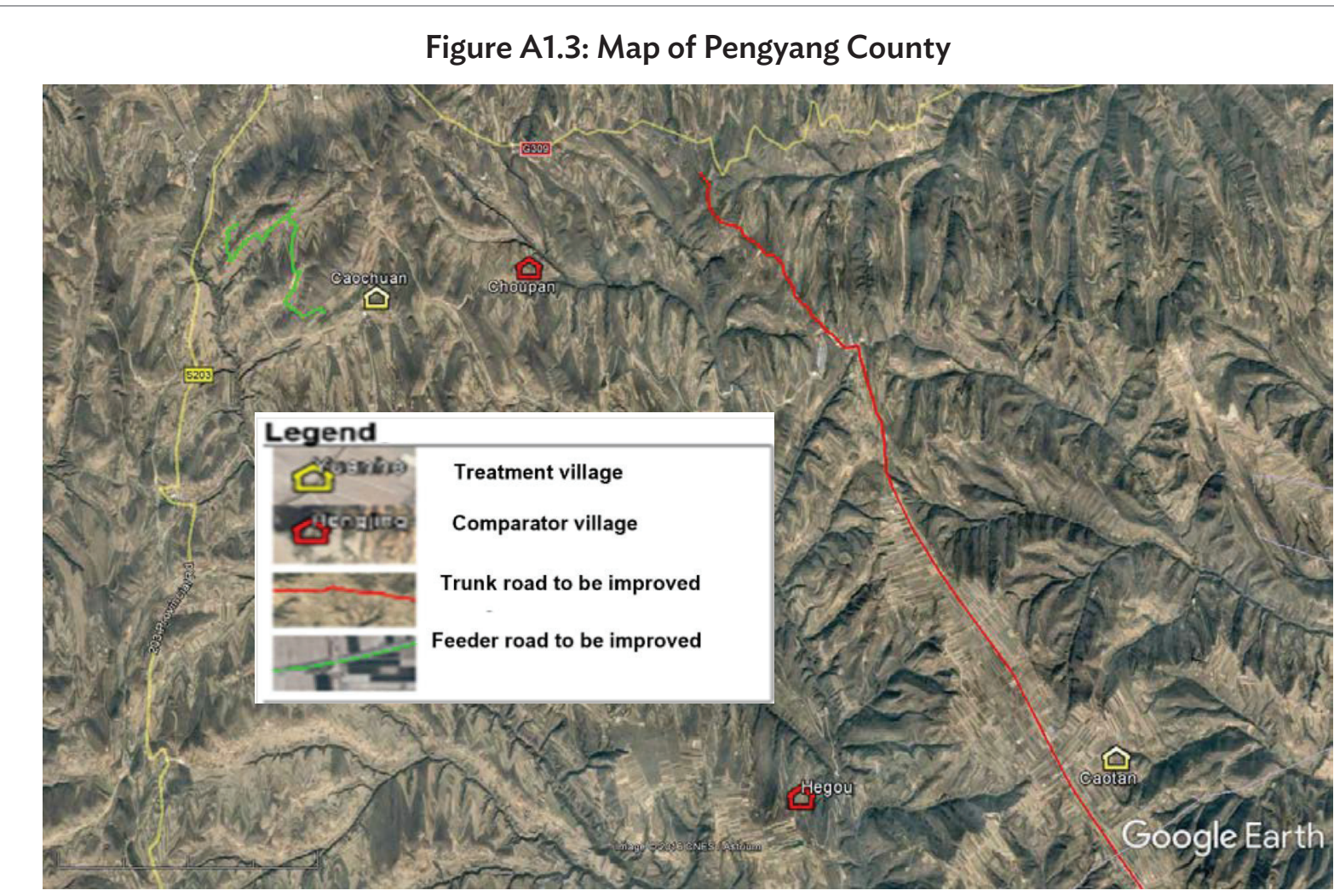

Note: Location of trunk and feeder roads near treatment and comparator villages. Map Data: Google Earth; Annotations: ADB.

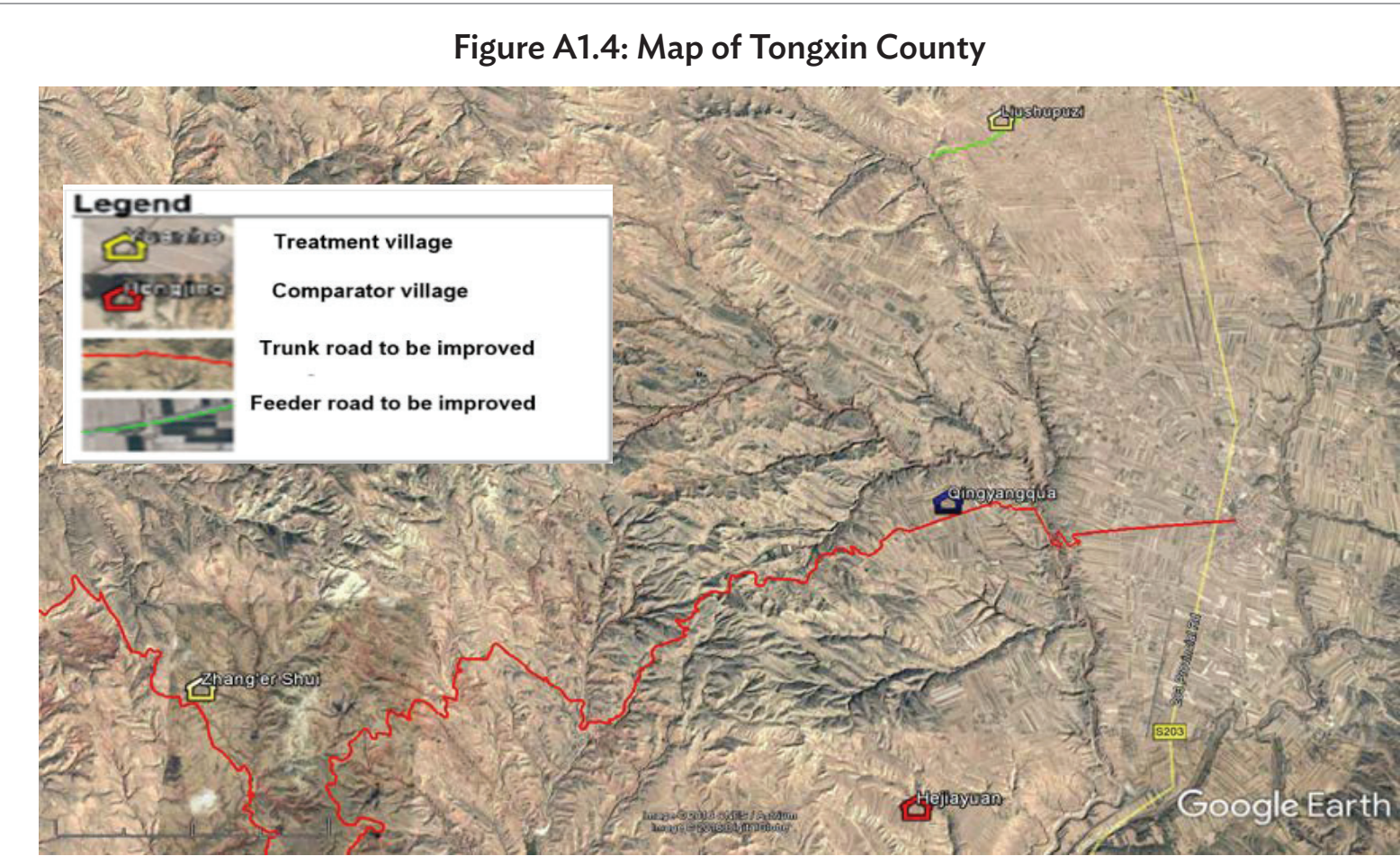

Note: Location of trunk and feeder roads near treatment and comparator villages. Map Data: Google Earth; Annotations: ADB. 


\section{Figure A1.5: Map of Xiji County}

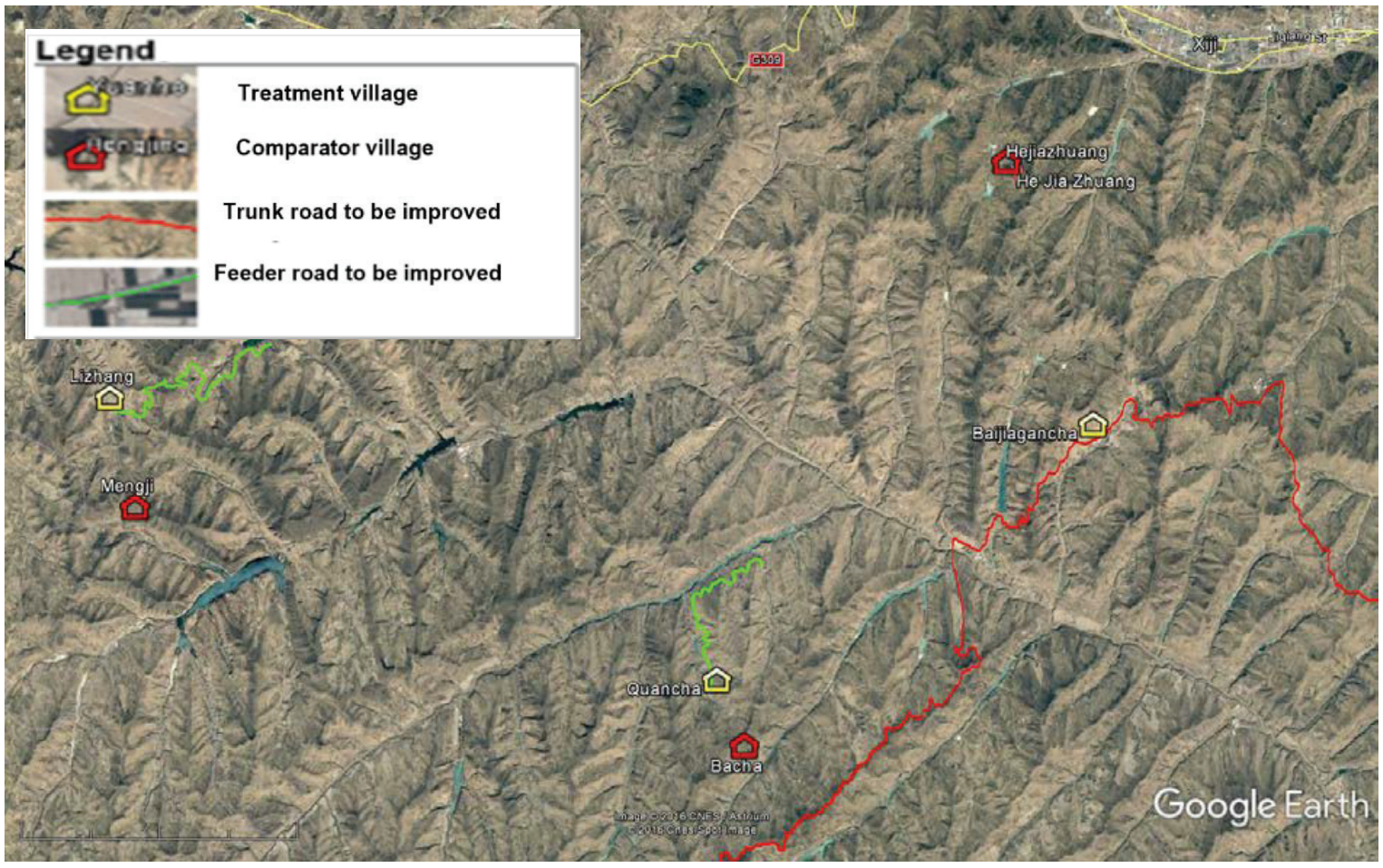

Note: Location of trunk and feeder roads near treatment and comparator villages. Map Data: Google Earth; Annotations: ADB.

\section{Figure A1.6: Map of Yuanzhou County (Northern Part)}

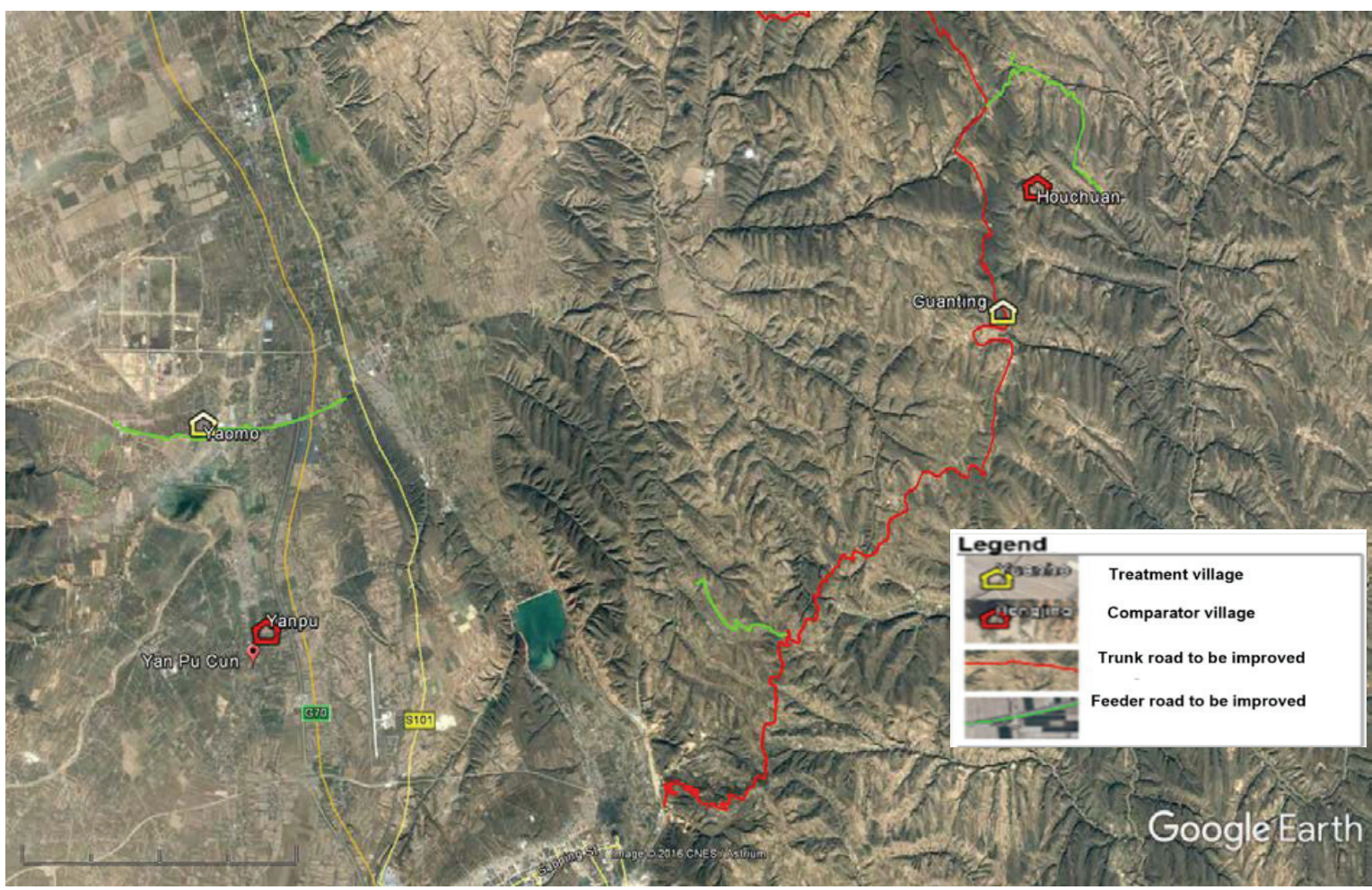

Note: Location of trunk and feeder roads near treatment and comparator villages. Map Data: Google Earth; Annotations: ADB. 


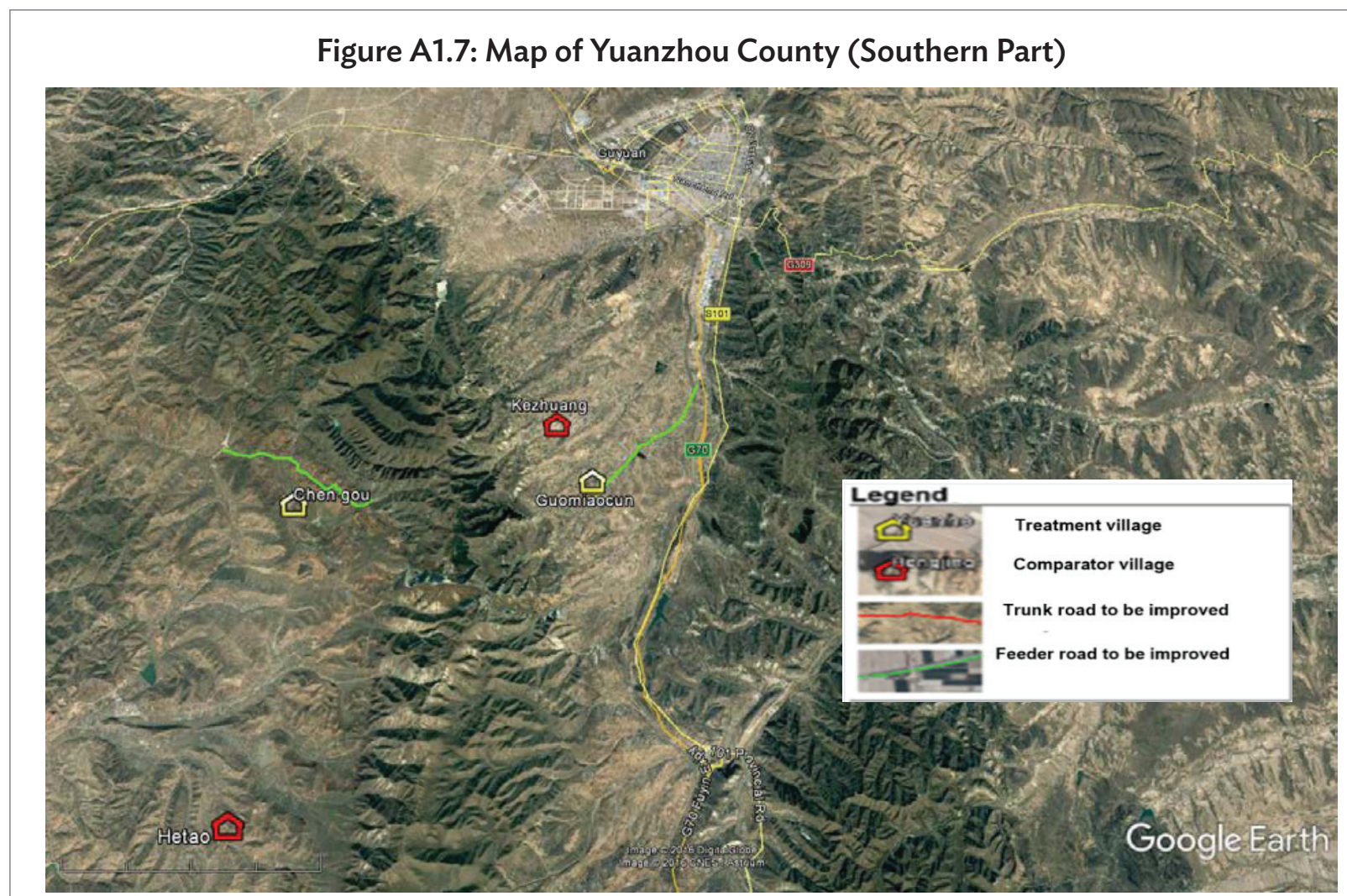

Note: Location of trunk and feeder roads near treatment and comparator villages. Map Data: Google Earth; Annotations: ADB. 


\section{ANNEX 2: HOUSEHOLD QUESTIONNAIRE}

\begin{tabular}{|c|c|c|c|}
\hline & Type & Question & Options \\
\hline 1 & Text & County name & \\
\hline 2 & Numeric & County code & \\
\hline 3 & Text & Township name & \\
\hline 4 & Numeric & Township code & \\
\hline 5 & Text & Administrative Village Name & \\
\hline 6 & Numeric & Administrative Village code & \\
\hline 7 & Text & Natural Village Name & \\
\hline 8 & Numeric & Natural Village code & \\
\hline 9 & Numeric & Household code & \\
\hline 10 & GPS & GPS location of household & \\
\hline 11 & $\begin{array}{l}\text { Single } \\
\text { Select }\end{array}$ & With whom is the interview conducted? & $\begin{array}{l}\text { 1. Head of household (male) } \\
\text { 2. Head of household (female) } \\
\text { 3. Son (>18 Years) } \\
\text { 4. Daughter (>18 years) } \\
\text { 5. Father } \\
\text { 6. Mather } \\
\text { 7. Other family members } \\
\text { 8. Other person }\end{array}$ \\
\hline 12 & Numeric & How many members has this household? & \\
\hline \multicolumn{4}{|c|}{$\begin{array}{l}\text { Household Members } \\
\text { This screen is the start of a set of repeating questions about the members of this household. To add a set of Repeating } \\
\text { Questions tap on 'Add Question Set' When you have finished adding Question Sets please press the next button at the top } \\
\text { right of this screen. }\end{array}$} \\
\hline 13 & $\begin{array}{l}\text { Single } \\
\text { Select }\end{array}$ & $\begin{array}{l}\text { Loop Household Members: Is this person the } \\
\text { present head of household? (Explanation: In case } \\
\text { that the man is a migrant worker, his wife is the } \\
\text { present head of household) }\end{array}$ & $\begin{array}{l}\text { 1. Yes } \\
\text { 2. No }\end{array}$ \\
\hline 14 & $\begin{array}{l}\text { Single } \\
\text { Select }\end{array}$ & Sex of household member & $\begin{array}{l}\text { 1. Male } \\
\text { 2. Female }\end{array}$ \\
\hline 15 & Numeric & Age of this person & \\
\hline 16 & $\begin{array}{l}\text { Single } \\
\text { Select }\end{array}$ & Health status of this person & $\begin{array}{l}\text { 1. Good health } \\
\text { 2. Chronic illness } \\
\text { 3. Serious illness } \\
\text { 4. Disabled }\end{array}$ \\
\hline 17 & Numeric & $\begin{array}{l}\text { How long did this person stay at home in } 2015 ? \\
\text { (months) }\end{array}$ & \\
\hline 18 & $\begin{array}{l}\text { Single } \\
\text { Select }\end{array}$ & Did this person work in the past year? & $\begin{array}{l}\text { 1. Yes } \\
\text { 2. No }\end{array}$ \\
\hline 19 & Numeric & $\begin{array}{l}\text { Number of migrant workers in this household } \\
\text { (workers work outside their townships for at least } \\
6 \text { month a year) }\end{array}$ & \\
\hline 20 & Numeric & Number of children in primary school & \\
\hline 21 & Numeric & Number of children in secondary school & \\
\hline
\end{tabular}


Annex 2 table continued

\begin{tabular}{|c|c|c|c|c|}
\hline & Type & \multicolumn{2}{|l|}{ Question } & Options \\
\hline 22 & Numeric & \multicolumn{2}{|c|}{$\begin{array}{l}\text { Number of children in high school or secondary } \\
\text { vocational school }\end{array}$} & \\
\hline 23 & Numeric & \multicolumn{2}{|c|}{$\begin{array}{l}\text { Number of children in boarding school including } \\
\text { primary, secondary and high schools }\end{array}$} & \\
\hline 24 & Numeric & \multicolumn{2}{|l|}{ Number of children in college and above } & \\
\hline 25 & $\begin{array}{l}\text { Multi } \\
\text { Select }\end{array}$ & \multicolumn{2}{|l|}{ Household endowment } & $\begin{array}{l}\text { 1. Washing Machine } \\
\text { 2. Refrigerator } \\
\text { 3. Colour Television } \\
\text { 4. Computer } \\
\text { 5. HiFi Stereo Component } \\
\text { 6. Camera } \\
\text { 7. Video Camera } \\
\text { 8. Microwave oven } \\
\text { 9. Mobile phone } \\
\text { 10. Electromagnetic oven } \\
\text { 11. None }\end{array}$ \\
\hline 26 & $\begin{array}{l}\text { Single } \\
\text { Select }\end{array}$ & \multicolumn{2}{|c|}{ Does this household have internet connection? } & $\begin{array}{l}\text { 1. Yes } \\
\text { 2. No }\end{array}$ \\
\hline 27 & $\begin{array}{l}\text { Single } \\
\text { Select }\end{array}$ & \multicolumn{2}{|l|}{ Does this household have running water? } & $\begin{array}{l}\text { 1. Yes } \\
\text { 2. No }\end{array}$ \\
\hline 28 & $\begin{array}{l}\text { Single } \\
\text { Select }\end{array}$ & \multicolumn{2}{|l|}{ Is drinking water safe? } & $\begin{array}{l}\text { 1. Yes } \\
\text { 2. No }\end{array}$ \\
\hline \multirow[t]{4}{*}{29} & \multirow[t]{4}{*}{ Grid Scale } & \multirow[t]{4}{*}{$\begin{array}{l}\text { General impression of the condition of } \\
\text { the household }\end{array}$} & & $\begin{array}{cccc}\text { very bad } & \text { bad } & \text { average } & \text { good } \\
\text { condition } & \text { very good } \\
\text { condition } & \text { condition } & \text { condition } & \text { condition }\end{array}$ \\
\hline & & & \multicolumn{2}{|c|}{ House outside } \\
\hline & & & \multicolumn{2}{|c|}{ House inaide } \\
\hline & & & \multicolumn{2}{|l|}{ Court yard } \\
\hline 30 & Numeric & $\begin{array}{l}\text { Number of persons employed from this } \\
\text { household }\end{array}$ & & \\
\hline \multicolumn{5}{|c|}{$\begin{array}{l}\text { Employment } \\
\text { Employment: This screen is the start of a set of repeating questions. To add a set of Repeating Questions tap on 'Add } \\
\text { Question Set' When you have finished adding Question Sets please press the next button at the top right of this screen. }\end{array}$} \\
\hline 31 & Numeric & \multicolumn{2}{|c|}{$\begin{array}{l}\text { Loop employment: How many hours per week is } \\
\text { this person working in } 2015 \text { ? [hours per week] }\end{array}$} & \\
\hline 32 & $\begin{array}{l}\text { Single } \\
\text { Select }\end{array}$ & \multicolumn{2}{|c|}{$\begin{array}{l}\text { In which economic sector is this person working } \\
\text { in } 2015 \text { ? }\end{array}$} & $\begin{array}{l}\text { 1. Primary Sector: Agriculture, Mining, Fishing } \\
\text { 2. Secondary Sector: Industry } \\
\text { 3. Tertiary Sector: Services }\end{array}$ \\
\hline 33 & $\begin{array}{l}\text { Single } \\
\text { Select }\end{array}$ & \multicolumn{2}{|l|}{ Where is this person employed in $2015 ?$} & $\begin{array}{l}\text { 1. Within Administrative Village } \\
\text { 2. Within this township } \\
\text { 3. Within this county (not migrant worker) } \\
\text { 4. Migrant worker outside this townships for at } \\
\text { least } 6 \text { months }\end{array}$ \\
\hline 34 & Numeric & \multicolumn{2}{|c|}{$\begin{array}{l}\text { How often per week does this person travel to the } \\
\text { place of employment in 2015. [trips per week] }\end{array}$} & \\
\hline
\end{tabular}


Annex 2 table continued

\begin{tabular}{|c|c|c|c|}
\hline & Type & Question & Options \\
\hline 35 & Numeric & $\begin{array}{l}\text { How many kilometres is this employment away } \\
\text { from home in } 2015 ?[\mathrm{~km}]\end{array}$ & \\
\hline 36 & $\begin{array}{l}\text { Single } \\
\text { Select }\end{array}$ & $\begin{array}{l}\text { Which means of transport does this person use } \\
\text { in } 2015 \text { ? }\end{array}$ & $\begin{array}{l}\text { 1. Walking } \\
\text { 2. Bicycle } \\
\text { 3. Motorcycle } \\
\text { 4. Own car } \\
\text { 5. Passenger in car } \\
\text { 6. Bus } \\
\text { 7. Electronic bicycle } \\
\text { 8. Train } \\
\text { 9. Airplane }\end{array}$ \\
\hline 37 & Numeric & $\begin{array}{l}\text { Travel time to place of employment in } 2015 \\
\text { (one way). [Minutes per one-way trip] }\end{array}$ & \\
\hline 48 & Numeric & $\begin{array}{l}\text { Cost per return trip to place of employment in } \\
2015 \text { [CNY per return trip] }\end{array}$ & \\
\hline 39 & Numeric & $\begin{array}{l}\text { Annual net income from this employment in } \\
\text { 2015. Please subtract all taxes and levies. Only } \\
\text { transfer is included for migrant workers } \\
\text { [CNY per year] }\end{array}$ & \\
\hline
\end{tabular}

\section{Crop Marketing}

This screen is the start of a set of repeating questions about crop marketing. Please enter the crops using the order of the village survey. To add a set of Repeating Questions tap on 'Add crop' When you have finished adding Question Sets please press the next button at the top right of this screen.

\begin{tabular}{|c|c|c|c|c|c|c|c|}
\hline 40 & Text & \multicolumn{3}{|c|}{$\begin{array}{l}\text { Name of crop Please use the name and sequence } \\
\text { of the village survey. }\end{array}$} & & & \\
\hline 41 & Numeric & \multicolumn{3}{|c|}{ Amount harvested in 2015 [Kg] } & & & \\
\hline 42 & Numeric & \multicolumn{3}{|l|}{ Amount marketed in 2015 [Kg] } & & & \\
\hline 43 & Numeric & \multicolumn{3}{|c|}{ Average price of this crop (yuan/500gram) } & & & \\
\hline 44 & $\begin{array}{l}\text { Single } \\
\text { Select }\end{array}$ & \multicolumn{3}{|c|}{ Where did you market this crop 2015? } & \multicolumn{3}{|c|}{$\begin{array}{l}\text { 1. Near the field } \\
\text { 2. Near the farmstead } \\
\text { 3. Village centre } \\
\text { 4. Near main road } \\
\text { 5. Main market town for this crop as given in the } \\
\text { village questionnaire } \\
\text { 6. Other Market [type name] }\end{array}$} \\
\hline \multirow[t]{5}{*}{45} & \multirow{5}{*}{$\begin{array}{l}\text { Grid - } \\
\text { Single } \\
\text { Select }\end{array}$} & \multirow{5}{*}{$\begin{array}{l}\text { How was the crop transported } \\
\text { to the market? }\end{array}$} & 1 & \multicolumn{2}{|l|}{ Motorcycle } & & \\
\hline & & & 2 & \multicolumn{2}{|l|}{ Car } & & \\
\hline & & & 3 & \multicolumn{2}{|c|}{ Agrimoto (Tricycle) } & 1 & Own vehicle \\
\hline & & & 4 & \multicolumn{2}{|c|}{ Light Goods Vehicle $<3.5$ tons } & 2 & Hired vehicle (as well from neighbors or village) \\
\hline & & & 5 & \multicolumn{2}{|c|}{ Heavy Goods Vehicle $>3.5$ tons } & 3 & Vehicle of a trader \\
\hline 46 & Numeric & \multicolumn{3}{|c|}{$\begin{array}{l}\text { Did you pay to transport this crop to the market? } \\
\text { If yes, how much did you pay for this crop in } 2015 \text { ? } \\
\text { [CNY] }\end{array}$} & & & \\
\hline
\end{tabular}


Annex 2 table continued

\begin{tabular}{|l|l|l|l|}
\hline & \multicolumn{1}{|c|}{ Type } & \multicolumn{1}{|c|}{ Question } & \multicolumn{1}{c|}{ Options } \\
\hline 47 & Numeric & $\begin{array}{l}\text { Did you lose any crops in 2015 due to transport } \\
\text { constraints? for example: no transport service } \\
\text { available, or road impassable. [Amount lost in kg] }\end{array}$ & \\
\hline 48 & Text & If there were losses, please specify & \\
\hline 49 & Numeric & How many trees did you grow and market in 2015? & $\begin{array}{l}\text { How much did you get from selling the trees } \\
\text { in 2015? }\end{array}$ \\
\hline 50 & Numeric & & \\
\hline
\end{tabular}

\section{Livestock Marketing}

This screen is the start of a set of repeating questions on livestock marketing. To add a set of Repeating Questions tap on 'Add Question Set' When you have finished adding Question Sets please press the next button at the top right of this screen.

\begin{tabular}{|c|c|c|c|c|c|}
\hline 51 & Text & \multicolumn{2}{|c|}{$\begin{array}{l}\text { Name of livestock marketed } 2015 \text {. Use the } \\
\text { sequence of livestock mentioned in the village } \\
\text { survey. }\end{array}$} & & \\
\hline 52 & Numeric & \multicolumn{2}{|c|}{ Number of this livestock raised in 2015} & & \\
\hline 53 & Numeric & \multicolumn{2}{|c|}{ Number of this livestock marketed in 2015} & & \\
\hline 54 & Numeric & \multicolumn{2}{|c|}{ Average price of this livestock (yuan/per animal) } & & \\
\hline 55 & $\begin{array}{l}\text { Single } \\
\text { Select }\end{array}$ & \multicolumn{2}{|c|}{ Where did you market this animal in $2015 ?$} & \multicolumn{2}{|c|}{$\begin{array}{l}\text { 1. Near the field } \\
\text { 2. Near the farmstead } \\
\text { 3. Village centre } \\
\text { 4. Near main road } \\
\text { 5. Main market town for this crop as given in the } \\
\text { village questionnaire } \\
\text { 6. Other Market [type name] }\end{array}$} \\
\hline \multirow[t]{5}{*}{56} & \multirow{5}{*}{$\begin{array}{l}\text { Grid - } \\
\text { Single } \\
\text { Select }\end{array}$} & \multicolumn{2}{|c|}{ How was the animal transported to the market? } & 1 & Motorcycle \\
\hline & & 1 & Own vehicle & 2 & Car \\
\hline & & 2 & Hired vehicle (as well from neighbors or village) & 3 & Agrimoto (Tricycle) \\
\hline & & \multirow{2}{*}{\multicolumn{2}{|c|}{3 Vehicle of a trader }} & 4 & Light Goods Vehicle $<3.5$ tons \\
\hline & & & & 5 & Heavy Goods Vehicle $>3.5$ tons \\
\hline 57 & Numeric & \multicolumn{2}{|c|}{$\begin{array}{l}\text { Did you pay to transport the livestock to the } \\
\text { market in 2015? If yes, how much? [CNY in 2015] }\end{array}$} & & \\
\hline 58 & Numeric & \multicolumn{2}{|c|}{$\begin{array}{l}\text { Estimate how much total income did your family } \\
\text { receive by selling animal products (milk. wool, eggs } \\
\text { etc.) in } 2015 \text { ? } \\
\text { [CNY per year] (exclude livestock themselves) }\end{array}$} & & \\
\hline 59 & Numeric & \multicolumn{2}{|c|}{$\begin{array}{l}\text { Estimate how much total cost did your family } \\
\text { spend for crop production in } 2015 \text { ? (costs include } \\
\text { fertilizer, seeds, pesticide, plastic sheet, machine } \\
\text { fees, electricity, fuel, irrigation, paid workers, etc.) } \\
\text { [CNY per year] }\end{array}$} & & \\
\hline 60 & Numeric & \multicolumn{2}{|c|}{$\begin{array}{l}\text { Estimate how much total cost did your family } \\
\text { spend for livestock production in } 2015 \text { ? (costs } \\
\text { include newborn animal, feed, medicine, paid } \\
\text { workers, machine fees, fuel, electricity, etc.) } \\
\text { [CNY per year] }\end{array}$} & & \\
\hline
\end{tabular}


Annex 2 table continued

\begin{tabular}{|c|c|c|c|}
\hline & Type & Question & Options \\
\hline 61 & Numeric & $\begin{array}{l}\text { Estimate how much total cost did your family } \\
\text { spend for tree planting in } 2015 \text { ? (costs include } \\
\text { fertilizer, seeds, pesticide, plastic sheet, machine } \\
\text { fees, electricity, fuel, irrigation, paid workers, etc.) } \\
\text { [CNY per year] }\end{array}$ & \\
\hline 62 & Numeric & $\begin{array}{l}\text { Did your family run non-agricultural businesses in } \\
2015 \text { ? } \\
\text { If yes, how high was the net income? } \\
\text { [CNY per year] }\end{array}$ & \\
\hline 63 & Numeric & How much did you get from public transfer? & \\
\hline 64 & Numeric & How much did you get from private transfer? & \\
\hline 65 & Numeric & $\begin{array}{l}\text { How much did you spend on food in recent half } \\
\text { month [CNY per year] (food consumption include } \\
\text { all food items consumed in recent half month } \\
\text { ether self-produced or purchased from market, } \\
\text { food items include: stable food, oil, meat, eggs, } \\
\text { milk, fish, cakes, soft drinks, condiment, cigarette, } \\
\text { alcoholic drinks, etc.) }\end{array}$ & \\
\hline 66 & Numeric & $\begin{array}{l}\text { How much did you spend on clothes including } \\
\text { bedclothes in } 2015 \text { [CNY per year] }\end{array}$ & \\
\hline 67 & Numeric & $\begin{array}{l}\text { How much did you spend on education and } \\
\text { entertainment in } 2015 \text { [CNY per year] }\end{array}$ & \\
\hline 68 & Numeric & $\begin{array}{l}\text { How much did you spend on medicine and } \\
\text { medical services in } 2015 \text { [CNY per year] }\end{array}$ & \\
\hline 69 & Numeric & $\begin{array}{l}\text { How much did you spend on durable goods in } \\
2015 \text { [CNY per year] }\end{array}$ & \\
\hline 70 & Numeric & $\begin{array}{l}\text { How much did you spend on communication in } \\
2015 \text { [CNY per year] }\end{array}$ & \\
\hline 71 & Numeric & $\begin{array}{l}\text { How much did you spend on transportation other } \\
\text { than income generation activities in } 2015 \\
\text { [CNY per year] }\end{array}$ & \\
\hline 72 & Numeric & $\begin{array}{l}\text { How much did you spend on housing including } \\
\text { furniture and utilities (water, electricity, gas or } \\
\text { coal) in } 2015 \text { [CNY per year] }\end{array}$ & \\
\hline 73 & Numeric & $\begin{array}{l}\text { Distance from your household to the nearest } \\
\text { paved road }[\mathrm{km}]\end{array}$ & \\
\hline 74 & Numeric & $\begin{array}{l}\text { How do you reach the paved road? } \\
\text { Select several if relevant. }\end{array}$ & $\begin{array}{l}\text { 1. On a gravel road } \\
\text { 2. On a earth road } \\
\text { 3. On a track, trail or footpath }\end{array}$ \\
\hline 75 & Numeric & $\begin{array}{l}\text { Which restrictions do you experience in reaching } \\
\text { your homestead? }\end{array}$ & $\begin{array}{l}\text { 1. All year good access to my homestead } \\
\text { 2. Accessibility is intermittently restricted } \\
\text { 3. Accessibility is constrained all year round }\end{array}$ \\
\hline
\end{tabular}


Annex 2 table continued

\begin{tabular}{|c|c|c|c|}
\hline & Type & Question & Options \\
\hline 76 & Numeric & $\begin{array}{l}\text { For how many days of the year is your access } \\
\text { constrained? } \\
\text { If the whole year is constrained, fill in } 365 \text { days. }\end{array}$ & \\
\hline 77 & $\begin{array}{l}\text { Multi } \\
\text { Select }\end{array}$ & $\begin{array}{l}\text { Which means of transport are constrained during } \\
\text { this time? } \\
\text { Select several if relevant. }\end{array}$ & $\begin{array}{l}\text { 1. Two wheeled vehicles } \\
\text { 2. Automobile (excluding } 4 \times 4) \\
\text { 3. Four wheel drive car }(4 \times 4) \\
\text { 4. Tricycle (Agrimoto) } \\
\text { 5. Light goods vehicle (<3.5 tons) } \\
\text { 6. Heavy goods vehicle ( }>3.5 \text { tons) } \\
\text { 7. Ambulances } \\
\text { 8. None }\end{array}$ \\
\hline 78 & $\begin{array}{l}\text { Multi } \\
\text { Select }\end{array}$ & $\begin{array}{l}\text { Which means of transport does the household } \\
\text { possess }\end{array}$ & $\begin{array}{l}\text { 1. Bicycle } \\
\text { 2. Powered bicycle } \\
\text { 3. Motorcycle } \\
\text { 4. Automobile (excluding } 4 \times 4) \\
\text { 5. Four wheel drive car }(4 \times 4) \\
\text { 6. Tricycle (Agrimoto) } \\
\text { 7. Light goods vehicle (<3.5 tons) } \\
\text { 8. Heavy goods vehicle (>3.5 tons) } \\
\text { 9. Animal cart } \\
\text { 10. None }\end{array}$ \\
\hline 79 & $\begin{array}{l}\text { Single } \\
\text { select }\end{array}$ & $\begin{array}{l}\text { Which of your means of transport are used by } \\
\text { female household members? }\end{array}$ & $\begin{array}{l}\text { 1. Bicycle } \\
\text { 2. Powered bicycle } \\
\text { 3. Motorcycle } \\
\text { 4. Automobile (excluding } 4 \times 4) \\
\text { 5. Four wheel drive car }(4 \times 4) \\
\text { 6. Tricycle (Agrimoto) } \\
\text { 7. Light goods vehicle (<3.5 tons) } \\
\text { 8. Heavy goods vehicle ( }>3.5 \text { tons) } \\
\text { 9. Animal cart } \\
\text { 10. None }\end{array}$ \\
\hline 80 & Numeric & $\begin{array}{l}\text { How often do members of your household travel } \\
\text { to the county capital [return trips per year] } \\
\text { Please exclude trips for employment! If answers are } \\
\text { given per week, multiply with } 55 \text {. }\end{array}$ & \\
\hline 81 & $\begin{array}{l}\text { Single } \\
\text { Select }\end{array}$ & Which means of transport do you mostly use? & $\begin{array}{l}\text { 1. Walking } \\
\text { 2. Bicycle } \\
\text { 3. Motorcycle } \\
\text { 4. Own car } \\
\text { 5. Passenger in car } \\
\text { 6. Bus } \\
\text { 7. Powered bicycle } \\
\text { 8. None }\end{array}$ \\
\hline
\end{tabular}


Annex 2 table continued

\begin{tabular}{|c|c|c|c|}
\hline & Type & Question & Options \\
\hline 82 & Numeric & $\begin{array}{l}\text { How often do members of your household travel } \\
\text { to the Township Capital [return trips per year] } \\
\text { Please exclude trips for employment! If answers are } \\
\text { given per week, multiply with } 55 \text {. }\end{array}$ & \\
\hline 83 & $\begin{array}{l}\text { Single } \\
\text { Select }\end{array}$ & Which means of transport do you mostly use? & $\begin{array}{l}\text { 1. Walking } \\
\text { 2. Bicycle } \\
\text { 3. Motorcycle } \\
\text { 4. Own car } \\
\text { 5. Passenger in car } \\
\text { 6. Bus } \\
\text { 7. Powered bicycle } \\
\text { 8. None }\end{array}$ \\
\hline 84 & $\begin{array}{l}\text { Single } \\
\text { Select }\end{array}$ & $\begin{array}{l}\text { If you have children visiting primary school, which } \\
\text { means of transport do they use? Skip next question } \\
\text { if not relevant. }\end{array}$ & $\begin{array}{l}\text { 1. walking } \\
\text { 2. Bicycle } \\
\text { 3. Passenger on motorcycle } \\
\text { 4. Passenger in car } \\
\text { 5. Passenger on powered bicycle } \\
\text { 6. School bus } \\
\text { 7. Public bus } \\
\text { 8. None }\end{array}$ \\
\hline 85 & Numeric & $\begin{array}{l}\text { How long is the distance to the primary school? } \\
{[\mathrm{km}]}\end{array}$ & \\
\hline 86 & $\begin{array}{l}\text { Single } \\
\text { Select }\end{array}$ & $\begin{array}{l}\text { If you have children visiting secondary school, } \\
\text { which means of transport do they use? Boarding } \\
\text { school excluded, only daily trips! }\end{array}$ & $\begin{array}{l}\text { 1. walking } \\
\text { 2. Bicycle } \\
\text { 3. Passenger on motorcycle } \\
\text { 4. Passenger in car } \\
\text { 5. Passenger on powered bicycle } \\
\text { 6. School bus } \\
\text { 7. Public bus } \\
\text { 8. None }\end{array}$ \\
\hline 87 & Numeric & $\begin{array}{l}\text { How long is the distance to the secondary school? } \\
{[\mathrm{km}]}\end{array}$ & \\
\hline 88 & Numeric & $\begin{array}{l}\text { How often do members of your household travel } \\
\text { to the next bank? [return trips per year] Please } \\
\text { exclude trips for employment! If answers are given } \\
\text { per week, multiply with } 55 \text {. }\end{array}$ & \\
\hline 89 & $\begin{array}{l}\text { Single } \\
\text { Select }\end{array}$ & $\begin{array}{l}\text { Which means of transport do you mostly use for } \\
\text { trips to the bank? }\end{array}$ & $\begin{array}{l}\text { 1. Walking } \\
\text { 2. Bicycle } \\
\text { 3. Motorcycle } \\
\text { 4. Own car } \\
\text { 5. Passenger in car } \\
\text { 6. Bus } \\
\text { 7. Powered bicycle } \\
\text { 8. None }\end{array}$ \\
\hline
\end{tabular}


Annex 2 table continued

\begin{tabular}{|c|c|c|c|}
\hline & Type & Question & Options \\
\hline 90 & Numeric & $\begin{array}{l}\text { How often do members of your household travel } \\
\text { to the next health station [return trips per year] } \\
\text { Please exclude trips for employment! If answers are } \\
\text { given per week, multiply with } 55 \text {. }\end{array}$ & \\
\hline 91 & $\begin{array}{l}\text { Single } \\
\text { Select }\end{array}$ & $\begin{array}{l}\text { Which means of transport do you mostly use to } \\
\text { travel to the health station? }\end{array}$ & $\begin{array}{l}\text { 1. Walking } \\
\text { 2. Bicycle } \\
\text { 3. Motorcycle } \\
\text { 4. Own car } \\
\text { 5. Passenger in car } \\
\text { 6. Bus } \\
\text { 7. Powered bicycle } \\
\text { 8. None }\end{array}$ \\
\hline 92 & Numeric & $\begin{array}{l}\text { How often do members of your household travel } \\
\text { to the next hospital [return trips per year] Please } \\
\text { exclude trips for employment! If answers are given } \\
\text { per week, multiply with } 55 \text {. }\end{array}$ & \\
\hline 93 & $\begin{array}{l}\text { Single } \\
\text { Select }\end{array}$ & $\begin{array}{l}\text { Which means of transport do you mostly use to } \\
\text { travel to the hospital? }\end{array}$ & $\begin{array}{l}\text { 1. Walking } \\
\text { 2. Bicycle } \\
\text { 3. Motorcycle } \\
\text { 4. Own car } \\
\text { 5. Passenger in car } \\
\text { 6. Bus } \\
\text { 7. Powered bicycle } \\
\text { 8. None }\end{array}$ \\
\hline 94 & Numeric & $\begin{array}{l}\text { How often do members of your household travel } \\
\text { to the nearest market } \\
\text { [return trips per year] } \\
\text { Please exclude trips for employment! If answers are } \\
\text { given per week, multiply with } 55 \text {. }\end{array}$ & \\
\hline 95 & $\begin{array}{l}\text { Single } \\
\text { Select }\end{array}$ & Which means of transport do you mostly use? & $\begin{array}{l}\text { 1. Walking } \\
\text { 2. Bicycle } \\
\text { 3. Motorcycle } \\
\text { 4. Own car } \\
\text { 5. Passenger in car } \\
\text { 6. Bus } \\
\text { 7. Powered bicycle } \\
\text { 8. None }\end{array}$ \\
\hline 96 & $\begin{array}{l}\text { Photo } \\
\text { Capture }\end{array}$ & Picture of the house & \\
\hline
\end{tabular}




\section{ANNEX 3: VILLAGE QUESTIONNAIRE}

\begin{tabular}{|c|c|c|c|}
\hline No & Type & Question & Options \\
\hline 1 & Text & County name & \\
\hline 2 & Numeric & County code & \\
\hline 3 & Text & Township name & \\
\hline 4 & Numeric & Township code & \\
\hline 5 & Text & Administrative village name & \\
\hline 6 & Numeric & Administrative village code & \\
\hline 7 & Single Select & Is this a treatment village? & $\begin{array}{ll}\text { 1. } & \text { Yes } \\
\text { 2. No }\end{array}$ \\
\hline 8 & Numeric & $\begin{array}{l}\text { If this is a treatment village, what is the number of the improved } \\
\text { road? }\end{array}$ & \\
\hline 9 & Numeric & $\begin{array}{l}\text { If this is a comparator village, what is the number of the improved } \\
\text { road of the treatment village? }\end{array}$ & \\
\hline 10 & GPS & GPS Location of village centre & \\
\hline 11 & Numeric & How many Natural Villages has this Administrative Village? & \\
\hline 12 & Single Select & How is the terrain around the village? & $\begin{array}{l}\text { 1. Flat } \\
\text { 2. Undulating } \\
\text { 3. Hilly } \\
\text { 4. Mountainous }\end{array}$ \\
\hline 13 & Text & Anything else that needs to be mentioned to describe the village? & \\
\hline 14 & Numeric & Number of households in the administrative village & \\
\hline 15 & Numeric & Number of inhabitants in the administrative village & \\
\hline 16 & Numeric & Number of male inhabitants & \\
\hline 17 & Numeric & Number of children ( $<18$ years) & \\
\hline 18 & Numeric & Number elderly ( $>60$ years) & \\
\hline 19 & Numeric & $\begin{array}{l}\text { Number migrant workers (workers work outside their townships for } \\
\text { at least } 6 \text { months a year) }\end{array}$ & \\
\hline 20 & Numeric & $\begin{array}{l}\text { Number of poor inhabitants according to the assessment of PAO } \\
\text { Please enter the data provided by the Poverty Alleviation Office. }\end{array}$ & \\
\hline 21 & Grid Scale & $\begin{array}{l}\text { Important causes of poverty } \\
\text { 1. Illness } \\
\text { 2. Medical expenses } \\
\text { 3. Lack of labour } \\
\text { 4. Lack of skills } \\
\text { 5. Lack of water } \\
\text { 6. Lack of credit } \\
\text { 7. School expenses } \\
\text { 8. Bad road } \\
\text { 9. Other causes }\end{array}$ & $\begin{array}{l}\text { 1. Not important } \\
\text { 2. Slightly important } \\
\text { 3. Important } \\
\text { 4. Very important }\end{array}$ \\
\hline 22 & Text & $\begin{array}{l}\text { Anything else that needs to be mentioned to describe poverty in } \\
\text { the village? }\end{array}$ & \\
\hline 23 & Numeric & Total number of enterprises in the village & \\
\hline 24 & Numeric & $\begin{array}{l}\text { Total number of enterprises in the village: Primary Sector } \\
\text { (Agriculture, Mining, Fishing, Forestry) }\end{array}$ & \\
\hline
\end{tabular}


Annex 3 table continued

\begin{tabular}{|c|c|c|c|}
\hline No & Type & Question & Options \\
\hline 25 & Numeric & $\begin{array}{l}\text { Total number of enterprises in the village: Secondary Sector } \\
\text { (Industry) }\end{array}$ & \\
\hline 26 & Numeric & Total number of enterprises in the village: Tertiary Sector (Services) & \\
\hline 27 & Numeric & $\begin{array}{l}\text { Total number of employees working in enterprises in this } \\
\text { administrative village }\end{array}$ & \\
\hline 28 & Single Select & $\begin{array}{l}\text { Are there any crops produced and marketed in this village? e.g. } \\
\text { maize, wheat, millet, vegetables, etc }\end{array}$ & $\begin{array}{l}\text { 1. Yes } \\
\text { 2. No }\end{array}$ \\
\hline 29 & Numeric & $\begin{array}{l}\text { Total area under cultivation for crops within the village boundaries } \\
\text { [hectares] }\end{array}$ & \\
\hline \multicolumn{4}{|c|}{$\begin{array}{l}\text { Crops marketed } \\
\text { This screen is the start of a set of repeating questions about the crops marketed. Please list here all important crops sold in } \\
\text { the village. Start with the most important crop. To add a set of Repeating Questions tap on 'Add Question Set'. When you } \\
\text { have finished adding Question Sets please press the next button at the top right of this screen. }\end{array}$} \\
\hline 30 & Information & $\begin{array}{l}\text { Please note separately - the names of the crops in the order of } \\
\text { importance, - the market town where this crop is sold, and - give } \\
\text { this information to your fellow enumerators. This information must } \\
\text { be used in all the household questionnaires of this village using the } \\
\text { same names and numbers. }\end{array}$ & \\
\hline 31 & Text & $\begin{array}{l}\text { Name of the crop marketed. Please include only crops with large } \\
\text { values marketed. }\end{array}$ & \\
\hline 32 & Numeric & Price for marketing the crop within the village [CNY/500gram] & \\
\hline 33 & Text & Name of Market Town where the crop is mainly marketed. & \\
\hline 34 & Numeric & Price for marketing the crop in the Market Town [CNY/500gram] & \\
\hline 35 & Numeric & Distance to market town $[\mathrm{km}]$ & \\
\hline 36 & Numeric & Travel time with tricycle (agrimoto) [Minutes] & \\
\hline 37 & Numeric & $\begin{array}{l}\text { If vehicles or transport services are hired: Costs to transport this } \\
\text { crop to the market. Please calculate the price to transport one ton of } \\
\text { this crop to the market. [CNY / ton] }\end{array}$ & \\
\hline 38 & Multi Select & $\begin{array}{l}\text { What are the major transport constraints in crop production and } \\
\text { marketing? Pick Many }\end{array}$ & $\begin{array}{l}\text { 1. No major constraints in } \\
\text { crop transport } \\
\text { 2. Transport of inputs such } \\
\text { as fertilizer, pesticides etc } \\
\text { 3. Transport to and from the } \\
\text { fields } \\
\text { 4. Loading of crops within } \\
\text { the village } \\
\text { 5. Transport to the markets } \\
\text { 6. Spoilage of products } \\
\text { during transport } \\
\text { 7. Other transport } \\
\text { constraints }\end{array}$ \\
\hline 39 & Single Select & Were crops lost or wasted in the last year? & $\begin{array}{l}\text { 1. No loss } \\
\text { 2. Minor loss } \\
\text { 3. Large loss } \\
\text { 4. Very large loss }\end{array}$ \\
\hline
\end{tabular}


Annex 3 table continued

\begin{tabular}{|c|c|c|c|}
\hline No & Type & Question & Options \\
\hline 40 & Single Select & If crops were lost, what was the main reason? & $\begin{array}{l}\text { 1. Transport constraints no } \\
\text { traders } \\
\text { 2. Weather constraints } \\
\text { 3. Market not profitable } \\
\text { 4. None of the above }\end{array}$ \\
\hline 41 & Single Select & Are there any trees grown and sold? & $\begin{array}{l}\text { 1. Yes } \\
\text { 2. No }\end{array}$ \\
\hline 42 & Numeric & Total area cultivated with trees [hectares] & \\
\hline 43 & Numeric & $\begin{array}{l}\text { Average price for trees marketed within the village in } 2016 \\
{[C N Y \text { /tree }]}\end{array}$ & \\
\hline 44 & Numeric & $\begin{array}{l}\text { Average price for trees marketed outside the village in } 2016 \\
{[C N Y / \text { tree }]}\end{array}$ & \\
\hline 45 & Single Select & Is there any livestock bred and sold in this village? & $\begin{array}{l}\text { 1. Yes } \\
\text { 2. No }\end{array}$ \\
\hline
\end{tabular}

\section{Livestock Marketing}

This screen is the start of a set of repeating questions about livestock. To add a set of Repeating Questions tap on 'Add Animal' When you have finished adding Question Sets please press the next button at the top right of this screen.

\begin{tabular}{|c|c|c|c|}
\hline 46 & Information & $\begin{array}{l}\text { Please note separately - the names of the animals in the order of } \\
\text { importance, - give this information to your fellow enumerators. This } \\
\text { information must be used in all the household questionnaires of this } \\
\text { village using the same names and numbers. }\end{array}$ & \\
\hline 47 & Text & Name of livestock marketed & \\
\hline 48 & Numeric & Price for livestock marketed [CNY/animal] & \\
\hline 49 & Numeric & $\begin{array}{l}\text { If vehicles or transport services are hired: Costs to transport this } \\
\text { animal to the market. Please calculate the price to transport one } \\
\text { animal to the market. [CNY/animal] }\end{array}$ & \\
\hline 50 & Text & Constraints in livestock marketing, if any? & \\
\hline 51 & Numeric & Distance to County Capital [km] & \\
\hline 52 & Numeric & Travel time to County Capital by public transport [Minutes] & \\
\hline 53 & Numeric & Travel time to County Capital with own car [Minutes] & \\
\hline 54 & Numeric & Travel time to County Capital with motorcycle [Minutes] & \\
\hline 55 & Numeric & Travel cost by public transport [CNY per return trip] & \\
\hline 56 & Numeric & Distance Township government [km] & \\
\hline 57 & Numeric & Travel time Township government with public transport [Minutes] & \\
\hline 58 & Numeric & Travel time Township government with own car [Minutes] & \\
\hline 59 & Numeric & Travel time Township government with motorcycle [Minutes] & \\
\hline 60 & Numeric & $\begin{array}{l}\text { Travel cost by public transport to township government } \\
\text { [CNY per return trip] }\end{array}$ & \\
\hline 61 & Text & $\begin{array}{l}\text { Where is the next bank that is frequently visited by villagers: Name } \\
\text { of town Please type all Chinese names in Pingying }\end{array}$ & \\
\hline 62 & Numeric & Distance to next bank $[\mathrm{km}]$ & \\
\hline 63 & Numeric & Travel time to next bank with public transport [Minutes] & \\
\hline 64 & Numeric & Travel time to next bank with own car [Minutes] & \\
\hline
\end{tabular}


Annex 3 table continued

\begin{tabular}{|c|c|c|c|}
\hline No & Type & Question & Options \\
\hline 65 & Numeric & Travel time to next bank with motorcycle [Minutes] & \\
\hline 66 & Numeric & Travel cost by public transport to next bank [CNY per return trip] & \\
\hline 67 & Text & $\begin{array}{l}\text { Where is the next health station that is frequently visited by } \\
\text { villagers: Name of town Please type all Chinese names in Pingying }\end{array}$ & \\
\hline 68 & Numeric & Distance to next health station $[\mathrm{km}]$ & \\
\hline 69 & Numeric & Travel time to next health station with public transport [Minutes] & \\
\hline 70 & Numeric & Travel time to next health station with own car [Minutes] & \\
\hline 71 & Numeric & Travel time to next health station with motorcycle [Minutes] & \\
\hline 72 & Numeric & $\begin{array}{l}\text { Travel cost by public transport to next health station } \\
\text { [CNY per return trip] }\end{array}$ & \\
\hline 73 & Text & $\begin{array}{l}\text { Where is the next hospital that is frequently visited by villagers: } \\
\text { Name of town Please type all Chinese names in Pingying }\end{array}$ & \\
\hline 74 & Numeric & Distance to next hospital $[\mathrm{km}]$ & \\
\hline 75 & Numeric & Travel time to next hospital with public transport [Minutes] & \\
\hline 76 & Numeric & Travel time to next hospital with own car [Minutes] & \\
\hline 77 & Numeric & Travel time to next hospital with motorcycle [Minutes] & \\
\hline 78 & Numeric & Travel cost by public transport to next hospital [CNY per return trip] & \\
\hline 79 & Numeric & $\begin{array}{l}\text { How many Natural Villages can be accessed directly by } \\
\text { ambulances? }\end{array}$ & \\
\hline 80 & Grid Scale & $\begin{array}{l}\text { Estimate which share of households in your Administrative Village } \\
\text { can be directly reached by ambulance? }\end{array}$ & $\begin{array}{l}\text { 1. No households accessed } \\
\text { 2. }<20 \% \\
\text { 3. } 20-39 \% \\
\text { 4. } 40-59 \% \\
\text { 5. } 60-79 \% \\
\text { 6. } 80-99 \% \\
\text { 7. } \text { All households }\end{array}$ \\
\hline 81 & Numeric & $\begin{array}{l}\text { Maximum distance sick persons are transported from their } \\
\text { household to the ambulance? [Meters] }\end{array}$ & \\
\hline 82 & Text & Any comments regarding ambulances & \\
\hline 83 & Numeric & Surfaced Roads: Road length within the village [meter] & \\
\hline 84 & Numeric & Gravelled Roads: Road length within the village [meter] & \\
\hline 85 & Numeric & Earth Roads: Road length within the village [meter] & \\
\hline 86 & Numeric & Number of vehicles available in the village: bicycles & \\
\hline 87 & Numeric & Number of vehicles available in the village: motorcycles & \\
\hline 88 & Numeric & Number of vehicles available in the village: tricycles (agrimoto) & \\
\hline 89 & Numeric & $\begin{array}{l}\text { Number of vehicles available in the village: light goods vehicles } \\
\text { (<3.5 tons) }\end{array}$ & \\
\hline 90 & Numeric & $\begin{array}{l}\text { Number of vehicles available in the village: heavy goods vehicles } \\
\text { (>3.5 tons) }\end{array}$ & \\
\hline 91 & Numeric & $\begin{array}{l}\text { Number of vehicles available in the village: passenger cars } \\
\text { (excluding } 4 \times 4 \text { ). }\end{array}$ & \\
\hline 92 & Numeric & $\begin{array}{l}\text { Number of vehicles available in the village: four wheel drive } \\
\text { passenger cars }(4 \times 4) \text { (Four wheel drive) }\end{array}$ & \\
\hline
\end{tabular}




\section{6 | Annex 3}

Annex 3 table continued

\begin{tabular}{|c|c|c|c|}
\hline No & Type & Question & Options \\
\hline 93 & Numeric & $\begin{array}{l}\text { How many days of year is internal access (within village) constrained } \\
\text { due to weather conditions? }\end{array}$ & \\
\hline 94 & Numeric & $\begin{array}{l}\text { How many days of year is external access (village) constrained due } \\
\text { to weather conditions? }\end{array}$ & \\
\hline 95 & Numeric & Bus transport services: Number of bus departures per weekday. & \\
\hline 96 & Numeric & How long is the bus stop away from the village centre? [km] & \\
\hline 97 & $\begin{array}{l}\text { Interval } \\
\text { Scale }\end{array}$ & $\begin{array}{l}\text { How do you assess the reliability of the bus services? Bus late, bus } \\
\text { does not show up, bus too early, etc. }\end{array}$ & $\begin{array}{l}\text { 1. Very bad } \\
\text { 2. Bad } \\
\text { 3. Average } \\
\text { 4. Good } \\
\text { 5. Very good }\end{array}$ \\
\hline 98 & $\begin{array}{l}\text { Multiple } \\
\text { selection }\end{array}$ & Road accident in recent 3 years & $\begin{array}{l}\text { 1. No accident } \\
\text { 2. Accident without human } \\
\text { injury } \\
\text { 3. Accident with minor injury } \\
\text { 4. Accident with serious } \\
\text { injury } \\
\text { 5. Accident with death }\end{array}$ \\
\hline 99 & Single select & $\begin{array}{l}\text { Are there any attractions in the village? (tourist attraction, } \\
\text { religious place) }\end{array}$ & $\begin{array}{l}\text { 1. Yes } \\
\text { 2. No }\end{array}$ \\
\hline 100 & Numeric & If yes, how many people come from outside? & \\
\hline 101 & Text & Free remark by enumerator regarding transport & \\
\hline 102 & Text & Free remark by enumerator regarding the whole questionnaire. & \\
\hline 103 & $\begin{array}{l}\text { Photo } \\
\text { Capture }\end{array}$ & Picture of administrative village council members & \\
\hline 104 & $\begin{array}{l}\text { Photo } \\
\text { Capture }\end{array}$ & Picture of administrative village council building & \\
\hline 105 & $\begin{array}{l}\text { Photo } \\
\text { Capture }\end{array}$ & Picture of road to be rehabilitated (treatment villages only) & \\
\hline 106 & $\begin{array}{l}\text { Photo } \\
\text { Capture }\end{array}$ & Village picture & \\
\hline 107 & $\begin{array}{l}\text { Photo } \\
\text { Capture }\end{array}$ & Village picture & \\
\hline
\end{tabular}


ANNEX 4: A COMPARISON BETWEEN THE RESULTS FOR THE TREATMENT AND COMPARATOR VILLAGES

\begin{tabular}{|c|c|c|c|c|c|c|c|c|c|c|c|c|}
\hline 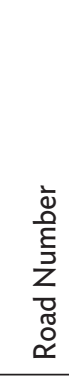 & County & Treatment Village & Comparator Village & 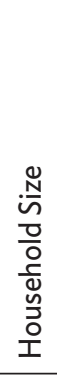 & 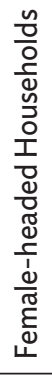 & 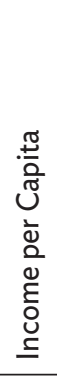 & 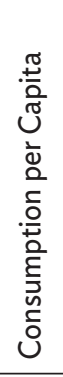 & 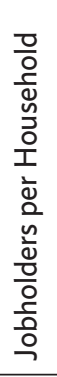 & 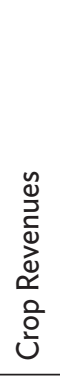 & 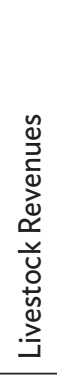 & 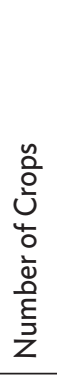 & 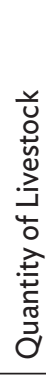 \\
\hline \multicolumn{13}{|c|}{ Trunk Roads } \\
\hline 01 & Haiyuan & Nanshan & Shabo & + & $\checkmark$ & + & $\checkmark$ & + & $\checkmark$ & $\checkmark$ & $\checkmark$ & $\checkmark$ \\
\hline 02 & Jingyuan & Shatang & Hongtu & $\checkmark$ & $\checkmark$ & $\checkmark$ & $\checkmark$ & $\checkmark$ & + & $\checkmark$ & $\checkmark$ & + \\
\hline 03 & Pengyang & Caotan & Hegou & + & + & $\checkmark$ & $\checkmark$ & $\checkmark$ & $\checkmark$ & $\checkmark$ & $\checkmark$ & $\checkmark$ \\
\hline 04 & Tongxin & Zhang'er Shui & Qingyangquan & $\checkmark$ & + & $\checkmark$ & $\checkmark$ & $\checkmark$ & + & $\checkmark$ & + & $\checkmark$ \\
\hline 05 & Xiji & Gancha & Hejiazhuang & + & $\checkmark$ & $\checkmark$ & $\checkmark$ & $\checkmark$ & + & $\checkmark$ & + & $\checkmark$ \\
\hline 06 & Yuanzhou & Guanting & Houchuan & + & + & $\checkmark$ & $\checkmark$ & $\checkmark$ & + & $\checkmark$ & + & + \\
\hline \multicolumn{13}{|c|}{ Feeder Roads } \\
\hline 07 & Haiyuan & Yuanhe & Hongjing & $\checkmark$ & $\checkmark$ & $\checkmark$ & + & $\checkmark$ & + & $\checkmark$ & + & $\checkmark$ \\
\hline 08 & Jingyuan & Pangdong & Xixian & $\checkmark$ & $\checkmark$ & + & $\checkmark$ & + & + & $\checkmark$ & + & $\checkmark$ \\
\hline 09 & Yuanzhou & Yaomo & Yanpu & $\checkmark$ & $\checkmark$ & $\checkmark$ & $\checkmark$ & + & + & $\checkmark$ & + & + \\
\hline 10 & Pengyang & Caochuan & Choupan & $\checkmark$ & $\checkmark$ & $\checkmark$ & $\checkmark$ & + & $\checkmark$ & $\checkmark$ & + & + \\
\hline 12 & Yuanzhou & Chen'er gou & Hetao & + & $\checkmark$ & $\checkmark$ & $\checkmark$ & $\checkmark$ & $\checkmark$ & $\checkmark$ & $\checkmark$ & $\checkmark$ \\
\hline 13 & Tongxin & Liushupuzi & Hejiayuan & $\checkmark$ & + & $\checkmark$ & $\checkmark$ & $\checkmark$ & + & $\checkmark$ & $\checkmark$ & $\checkmark$ \\
\hline 14 & $X_{i j i}$ & Quancha & Bacha & $\checkmark$ & $\checkmark$ & $\checkmark$ & $\checkmark$ & $\checkmark$ & $\checkmark$ & $\checkmark$ & + & + \\
\hline 15 & $X_{i j i}$ & Lizhang & Mengji & $\checkmark$ & + & + & + & $\checkmark$ & $\checkmark$ & $\checkmark$ & $\checkmark$ & $\checkmark$ \\
\hline 16 & Yuanzhou & Guomiaocun & Kezhuang & $\checkmark$ & $\checkmark$ & + & $\checkmark$ & + & $\checkmark$ & $\checkmark$ & $\checkmark$ & $\checkmark$ \\
\hline
\end{tabular}

Legend

$\checkmark$ No significant difference observed

+ Treatment village significantly higher

+ Comparator Village significantly higher

Source: Asian Development Bank (ADB). 


\section{Impact Evaluation of Road Improvements and Rural Poverty \\ Baseline Survey in the Ningxia Liupanshan Area of the People's Republic of China}

Rural road improvements indirectly benefit the poor by generating more income opportunities. The Asian Development Bank is financing a major road-improvement project in rural areas of the People's Republic of China. In order to assess the impacts of improved rural transport, two surveys are needed: a baseline survey conducted before project implementation and an ex-post survey conducted after the project's completion. The impacts can be discerned through a comparison of the surveys' results. This paper describes the methodology, implementation, and results of the baseline survey.

\section{About the Asian Development Bank}

ADB's vision is an Asia and Pacific region free of poverty. Its mission is to help its developing member countries reduce poverty and improve the quality of life of their people. Despite the region's many successes, it remains home to a large share of the world's poor. ADB is committed to reducing poverty through inclusive economic growth, environmentally sustainable growth, and regional integration.

Based in Manila, ADB is owned by 67 members, including 48 from the region. Its main instruments for helping its developing member countries are policy dialogue, loans, equity investments, guarantees, grants, and technical assistance. 